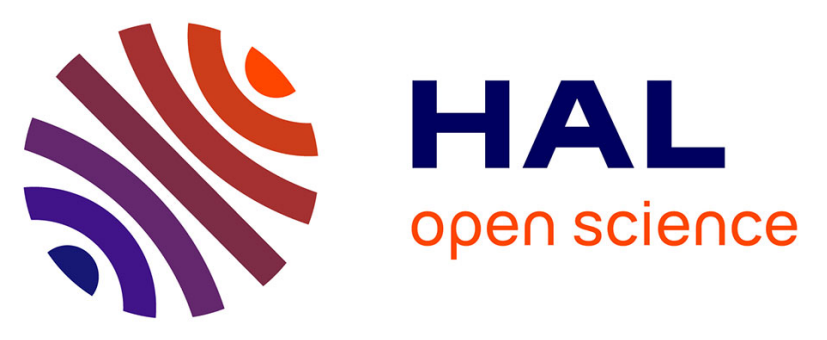

\title{
Structural and Geochronological Study of High-Pressure Metamorphic Rocks in the Kekesu Section (Northwestern China): Implications for the Late Paleozoic Tectonics of the Southern Tianshan
}

Bo Wang, Michel Faure, Liangshu S. Shu, Koenraad de Jong, Jacques

Charvet, Dominique Cluzel, Bor-Ming Jahn, Yan Chen, Gilles Ruffet

\section{To cite this version:}

Bo Wang, Michel Faure, Liangshu S. Shu, Koenraad de Jong, Jacques Charvet, et al.. Structural and Geochronological Study of High-Pressure Metamorphic Rocks in the Kekesu Section (Northwestern China): Implications for the Late Paleozoic Tectonics of the Southern Tianshan. Journal of Geology, 2010, 118, pp.59-77. 10.1086/648531 . insu-00440204

\section{HAL Id: insu-00440204 https://hal-insu.archives-ouvertes.fr/insu-00440204}

Submitted on 8 Jun 2020

HAL is a multi-disciplinary open access archive for the deposit and dissemination of scientific research documents, whether they are published or not. The documents may come from teaching and research institutions in France or abroad, or from public or private research centers.
L'archive ouverte pluridisciplinaire HAL, est destinée au dépôt et à la diffusion de documents scientifiques de niveau recherche, publiés ou non, émanant des établissements d'enseignement et de recherche français ou étrangers, des laboratoires publics ou privés. 


\title{
Structural and Geochronological Study of High-Pressure Metamorphic Rocks in the Kekesu Section (Northwestern China): Implications for the Late Paleozoic Tectonics of the Southern Tianshan
}

\author{
Bo Wang, ${ }^{1,2}$ Michel Faure, ${ }^{1}$ Liangshu Shu, Koen de Iong, ${ }^{1,3}$ Jacques Charvet, ${ }^{1}$ \\ Dominique Cluzel, ${ }^{1}$ Bor-ming Jahn, ${ }^{2}$ Yan Chen, ${ }^{1}$ and Gilles Ruffet ${ }^{4}$ \\ State Key Laboratory for Mineral Deposits Research, School of Earth Sciences and Engineering, \\ Nanjing University, 210093 Nanjing, China \\ (e-mail: burh_cw@yahoo.com)
}

\begin{abstract}
A B S T R A C T
Blueschist- and eclogite-facies high- to ultrahigh-pressure (HP/UHP) metamorphic rocks occur in the southern Tianshan Belt. Their deformation and metamorphic history is important for understanding the Paleozoic tectonics of the Central Asian Orogenic Belt. Our study focuses on the structural analysis and geochronology of the HP metamorphic rocks and the surrounding rocks in the Kekesu Section in the southern Chinese Tianshan. Geometric and kinematic analyses indicate three ductile deformation events: a top-to-the-north thrusting, a top-to-the-south shearing, and a dextral wrenching. New ${ }^{40} \mathrm{Ar} /{ }^{39} \mathrm{Ar}$ laser probe plateau ages were obtained on white mica from retrograde blueschist $(316 \pm 2$ and $331 \pm 1 \mathrm{Ma} ; 1 \sigma)$ and greenschist-facies metasediments $(323 \pm 1 \mathrm{Ma} ; 1 \sigma)$. These ages are interpreted as the time of retrograde recrystallization during exhumation of the HP metamorphic rocks. New structural and isotopic data, in conjunction with previous results, suggest that (1) the collision event occurred during the latest Devonian to earliest Carboniferous, resulting in HP/UHP metamorphism and the top-to-the-north thrusting; (2) the postcollisional exhumation of the HP/UHP metamorphic rocks and extensive retrograde metamorphism under greenschistfacies conditions took place in the Mid-Late Carboniferous and are correlated with south-dipping normal faulting; and (3) Permian ductile dextral shearing and associated granitic intrusion and fluid activity severely overprinted the earlier fabrics.
\end{abstract}

Online enhancements: table, color versions of figures.

\section{Introduction}

The Tianshan Belt forms the southernmost part of the Central Asian Orogenic Belt $\left(\mathrm{CAOB}\right.$; fig. $1 A_{\text {; }}$ e.g., Windley et al. 1990, 2007; Jahn et al. 2000; Jahn 2004; Xiao et al. 2004), which is otherwise known as the Altaid Tectonic Collage (Altaids; Şen-

Manuscript received February 24, 2009; accepted August 1, 2009.

${ }^{1}$ Institut des Sciences de la Terre d'Orléans, Unité Mixte de Recherche-Centre National de la Recherche Scientifique (UMR CNRS) 6113, Université d'Orléans, 45067 Orléans cedex 2, France.

${ }^{2}$ Institute of Earth Sciences, Academia Sinica, Taipei, 11529 Taiwan, Republic of China.

${ }^{3}$ School of Earth and Environmental Sciences, College of Natural Science, Seoul National University, Seoul 151-747, Korea.

${ }^{4}$ Géosciences Rennes, UMR CNRS 6118, Université de Rennes 1, 35042 Rennes, France.

gör et al. 1993; Şengör and Natal'in 1996). The Tianshan Belt extends east-west for more than $2500 \mathrm{~km}$ from China to Kazakhstan and Kyrgyzstan (fig. 1). Geologically, the Tianshan Belt is divided into three tectonic units: north, central, and south Tianshan (e.g., Xiao et al. 1992; Mikolaichuk et al. 1995; Gao et al. 1998, 2009). However, there is often confusion in correlating the subunits of Chinese Tianshan with the corresponding units in the Kazakh and Kyrgyz Tien Shan. Geographically, the Tianshan range is separated into southern and northern parts by the Mesozoic-Cenozoic Kazakh-Yili and Tu-Ha basins (fig. 1B, 1C). In this study, the term "Southern Tianshan" refers geographically to the area between the Kazakh-Yili and Tarim basins.

In the Southern Tianshan, blueschist- and eclogite-facies metamorphic rocks are exposed in the 


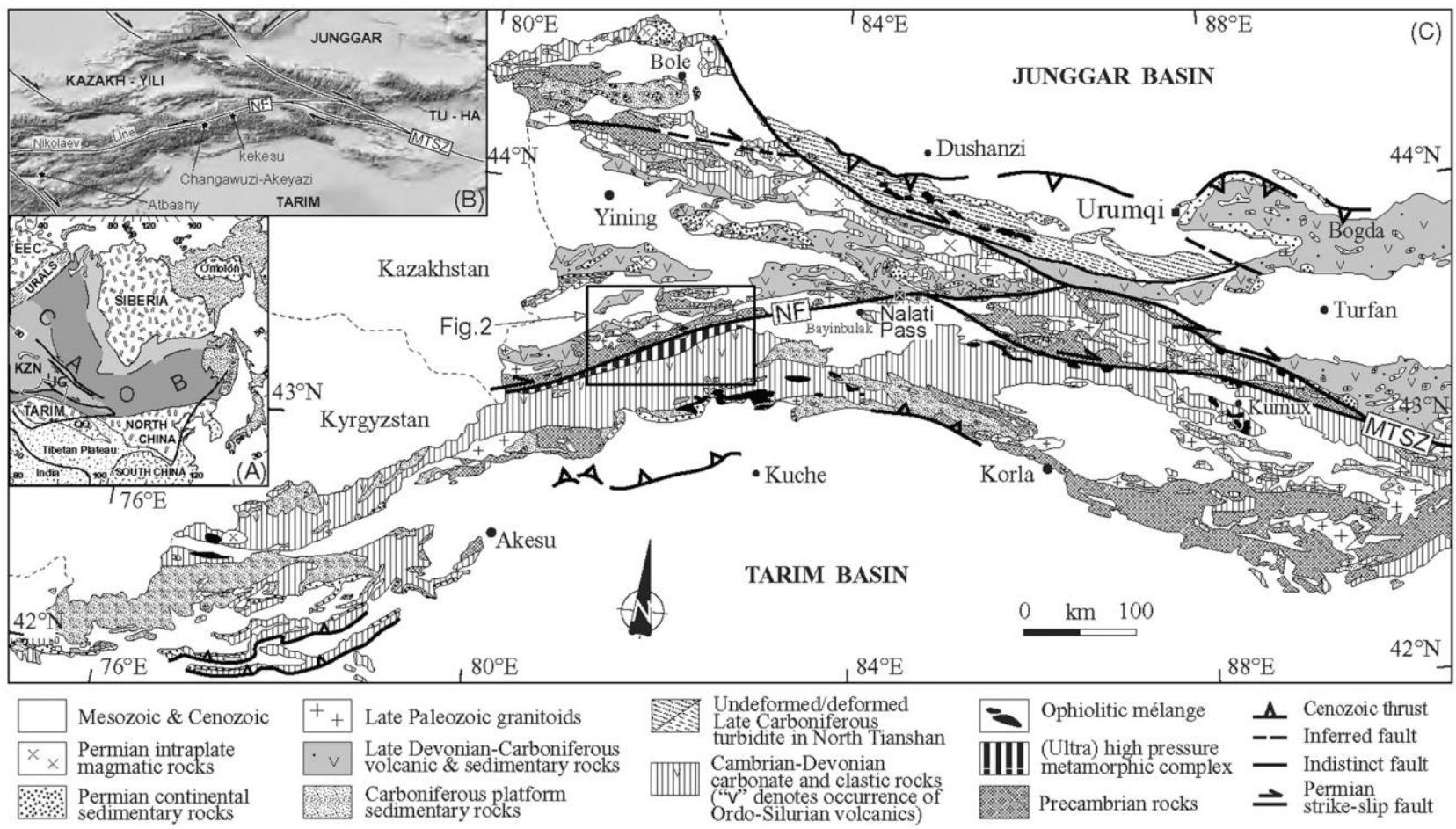

Figure 1. Geological map of the western Chinese Tianshan Belt (modified from XBGMR 1993). Inset $A$ (modified from Jahn 2004; de Jong et al. 2009) indicates the location of the study area within the tectonic framework of eastern Eurasia; inset $B$ shows the topographic image of the Tianshan Mountains and adjacent sedimentary basins; black stars refer to high-pressure metamorphic belts. $C A O B=$ Central Asian Orogenic Belt, $E E C=$ East European Craton, $J G=$ Junggar, $K Z N=$ Kazakhstan, $M T S Z=$ Main Tianshan Shear Zone, $N F=$ Nalati Fault, and $Q Q=$ Qaidam Qinling.

Kekesu and Changawuzi-Akyazi areas in northwestern China (e.g., Gao et al. 1995; Zhang et al. 2003 ) and the Atbashy area in Kyrgyzstan (fig. 1B; e.g., Tagiri et al. 1995). Deciphering the deformation and metamorphic history of these high-pressure $(\mathrm{HP})$ and ultra-HP (UHP) metamorphic rocks is essential for reconstructing the tectonic evolution of the Tianshan Belt as well as that of the CAOB. A considerable number of mineralogical, petrological, and geochemical data on these HP/ UHP metamorphic rocks have been documented (Gao et al. 1995, 1999; Tagiri et al. 1995; Klemd 2003; Wei et al. 2003; Zhang et al. 2003 and references therein; Lin and Enami 2006; Li et al. 2007; Lü et al. 2008; Simonov et al. 2008; Su et al. 2009). However, their structural characteristics are insufficiently studied (Gao et al. 1995; Lin et al. 2009). Moreover, although numerous geochronological studies have been conducted (Dobretsov et al. 1987; Xiao et al. 1990; Hao and Liu 1993; Gao et al. 1995, 2000; Gao and Klemd 2003; Klemd et al. 2005; Zhang et al. 2007; Simonov et al. 2008), there is no consensus on the age of the HP/UHP metamor- phism. Consequently, some authors have argued that the final collisional orogeny of the Southern Tianshan occurred in the late Paleozoic (e.g., Gao et al. 1998, 2006; Stupakov et al. 2004), whereas others argue for a Triassic collision (e.g., Zhang et al. 2007; Xiao et al. 2008).

The Tianshan Belt is a classical example of a reactivated intracontinental orogen. Complicated reactivations severely modified the pre-Permian regional structure of the Tianshan Belt (Wang et al. 2006, 2008a), causing difficulties in reconstructing its original tectonic architecture. This study focuses on a key transect through the southern Chinese Tianshan along the Kekesu River. We present field observations, detailed structural analyses, and new ${ }^{40} \mathrm{Ar} /{ }^{39} \mathrm{Ar}$ dating results of partially retrogressed HP metamorphic rocks as well as of greenschist-facies metasedimentary rocks. These data allow us to distinguish different phases of deformation, to remove the postcollisional tectonothermal overprints, and to constrain the timing of collisional phases. Then, on the basis of a synthesis of previous works, we discuss the implications of 


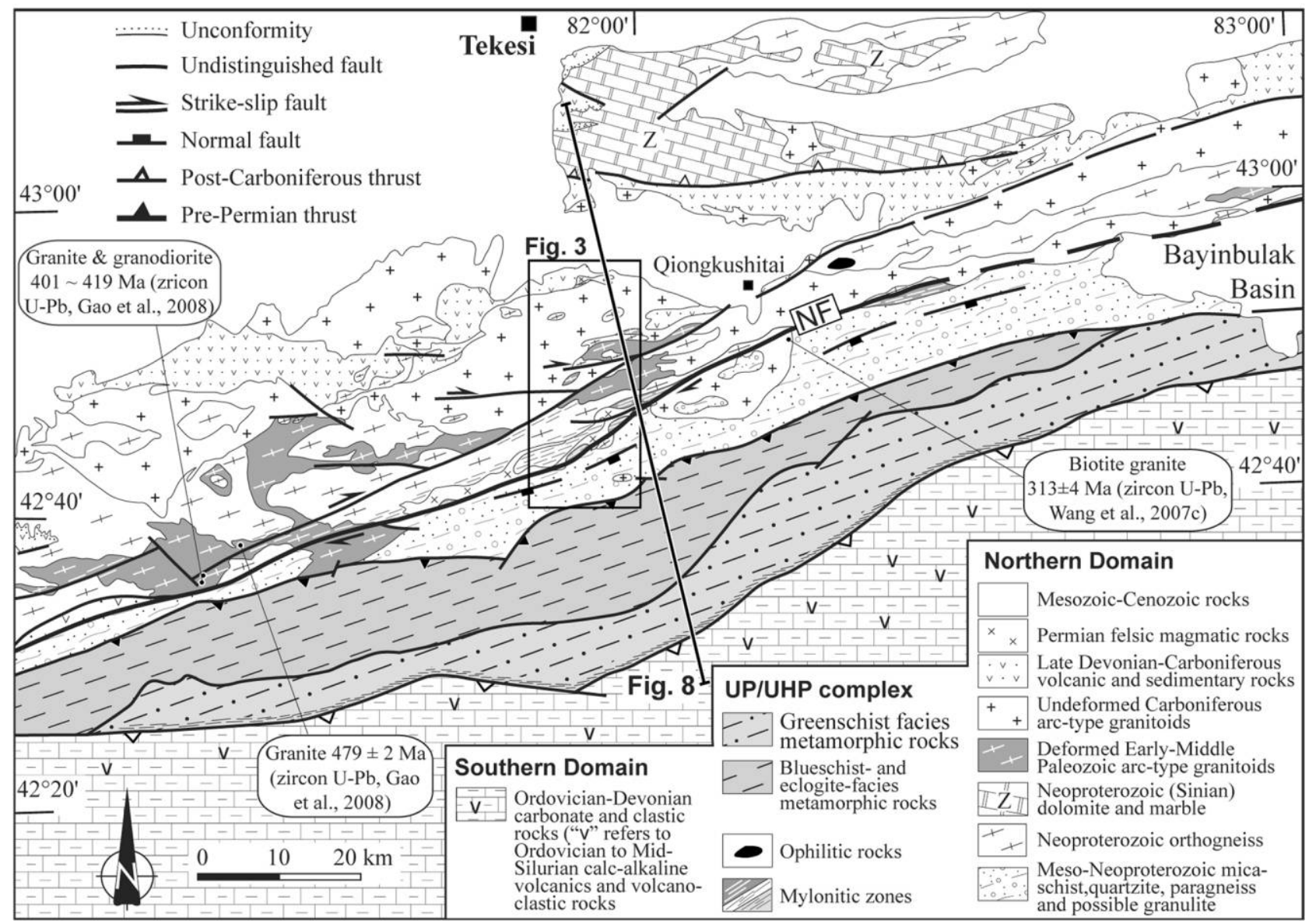

Figure 2. Geological map of the southwestern Chinese Tianshan (modified from XBGMR 1979, 1981, 1983; Gao et al. 1995; Gao 2000; Zhu 2007). NF = Nalati Fault; $Z=$ Sinian ("Zhendan" in Chinese).

our new results for the tectonic evolution of the Southern Tianshan.

\section{Geological Overview}

The Tianshan Belt is considered to have formed by Paleozoic polyphase accretion and amalgamation of magmatic arc complexes, continental fragments, and microcontinents (Windley et al. 1990; Allen et al. 1993; Gao et al. 1998; Shu et al. 2000, 2002; Xiao et al. 2004, 2008). The belt was overprinted by subsequent crust-scale transcurrent faulting (fig. $1 B$, 1C; Allen et al. 1995; Allen and Vincent 1997; Shu et al. 1999; Laurent-Charvet et al. 2002, 2003; Wang et al. 2006) and subjected to regional magmatism and fluid infiltration (Allen et al. 1993; de Jong et al. 2009; Wang et al. 2009). In addition, distant influence of the Cenozoic Indo-Asia collision induced a north-south crustal shortening that is accommodated by north- and south-directed thrusting of Paleozoic units over the meso-Cenozoic Junggar and Tarim basins, respectively (fig. $1 C$; e.g., Avouac et al. 1993; Allen et al. 1999; Burchfiel et al. 1999; Shu et al. 2003).

In the Southern Tianshan, the Nalati Fault (NF; fig. $1 B, 1 C)$ extends to the east, connecting with the Main Tianshan Shear Zone (MTSZ; fig. 1B, 1C; Shu et al. 1999; Laurent-Charvet et al. 2003), and continues westward into Kyrgyzstan, likely joining with the Nikolaev Line, which was described as a sublatitudinal steep fault (fig. $1 B$ ) by Mikolaichuk et al. (1995). These faults form a distinct structure in the Southern Tianshan (fig. 1B), but they are basically Permian shear zones (Mikolaichuk et al. 1995; Yin and Nie 1996; Wang et al. 2008a); their significance before the Permian is not clearly understood. Numerous ophiolitic relics crop out discontinuously along the Nalati Fault, and HP metamorphic rocks have been recognized mainly to the south of this fault zone (fig. 1A; fig. 2; e.g., Gao et al. 2009 and references therein). The ophiolites and HP metamorphic rocks have been defined as a su- 
ture zone (Windley et al. 1990; Allen et al. 1993; Gao et al. 1998; Chen et al. 1999a; Wang et al. 2008a) separating the Southern Tianshan into northern and southern domains.

The northern domain is composed of undeformed and unmetamorphosed Late Devonian to Carboniferous arc-type magmatic and sedimentary rocks underlain by Precambrian substrata, including Neoproterozoic orthogneiss and carbonates, Mesoproterozoic metaclastic rocks, and Paleoproterozoic gneisses (XBGMR 1993). Early Paleozoic ductilely deformed calc-alkaline diorite and granite developed close to the Nalati Fault and the Nikolaev Line (Konopelko et al. 2008; Gao et al. 2009; Qian et al. 2009). This domain is considered the Yili-North Tianshan Block (Charvet et al. 2007; Wang et al. 2008a), or the "Kazakhstan (North Tien Shan)-Yili Plate" (Mikolaichuk et al. 1995; Gao et al. 2009). In this article, we use "Yili Block" for this microcontinental unit.

The southern domain is mainly represented by Ordovician to Devonian marble, dolomite, recrystallized limestone with intraformational breccia, and turbiditic flysch (XBGMR 1993; Wang et al. 1997). Within this series, Ordovician and MiddleLate Silurian calc-alkaline volcanic and volcaniclastic rocks have also been documented (fig. $1 C$; XBGMR 1981, 1983; Wang et al. 1997; Zhou et al. 2001; Gong et al. 2003; Zhu 2007). On the basis of the lithological assemblage, this domain is considered an Early Paleozoic continental active margin (Charvet et al. 2007; Wang et al. 2008a) instead of a passive margin of Tarim Plate, as suggested by previous authors (e.g., Gao et al. 1998; Chen et al. 1999a). The basement rocks are locally exposed (fig. $1 C)$ and consist of Neoproterozoic pegmatite ( 931 Ma by the zircon $\mathrm{U}-\mathrm{Pb}$ method), migmatite, marble, and metapelite ( $606 \mathrm{Ma}$ by the $\mathrm{Rb}$-Sr isochron method; Wang et al. 1996; Zhu 2007). In the southernmost part of this domain, highly deformed Silurian volcaniclastic rocks and mylonitized Devonian marble are tectonically overlain by an Early Carboniferous ophiolitic mélange, along which Late Silurian to Devonian ophiolitic rocks occur discontinuously, separating the Tianshan Belt from the Tarim Block (fig. 1C; Wang et al. 2008a and references therein).

\section{Lithology and Bulk Geometry of the Kekesu Section}

The transect studied here extends north-south, parallel to the Kekesu River. Four lithotectonic units have been recognized (figs. 2, 3A). From north to south, they are described in the following subsections.

Magmatic Arc Sequence. The northernmost part of the Kekesu Section is dominated by Late Devonian to Carboniferous limestone and sandstone associated with magmatic rocks (XBGMR 1993). Volcanic rocks are composed of basalt, basaltic andesite, andesite, rhyolite, trachyte, and tuff. Basalts yielded a ${ }^{40} \mathrm{Ar} /{ }^{39} \mathrm{Ar}$ whole-rock isochron age of $326 \pm 15 \mathrm{Ma}$ (Liu et al. 1994), and basaltic andesites were dated at $363 \pm 4$ to $354 \pm 5$ and $313 \pm 4 \mathrm{Ma}$ (zircon SHRIMP U-Pb; Zhu et al. 2005, 2006b). The granitoids consist of coarse-grained diorite, granodiorite, tonalite, K-feldspar granite, and minor pegmatite. Zircon U-Pb (LA-ICPMS and SHRIMP) ages of hornblende-bearing granite and K-granite range from $352 \pm 6$ to $338 \pm 8 \mathrm{Ma}$ (figs. 2, 3; Wang et al. 2007c; Gao et al. 2009); a biotite granite of $313 \pm$ $4 \mathrm{Ma}$ intrudes the greenschist-facies metasedimentary rocks occurring to the south of Qiongkushitai (fig. 2; Wang et al. 2007c).

Trace-element geochemistry of these magmatic rocks indicates that they are calc-alkaline in composition and were generated in an active continental margin of the Yili Block (Zhu et al. 2006a; Wang et al. 2007c; Gao et al. 2009). The geochemical and geochronological data are comparable with those of magmatic rocks in the north of the Yili Arc (Jiang et al. 1995; Wang et al. 2006, 2007b; Zhai et al. 2006), which is considered a result of a southward subduction of an oceanic plate beneath the Yili Block (fig. 1C; Wang et al. 2006, 2007b, 2008a).

In addition, arc-type diorite, granodiorite, and granite with ages of 398-436 and 466-479 Ma developed both in this area (figs. 2, 3; Gao et al. 2009; Qian et al. 2009) and in the adjacent Kyrgyz North Tien Shan (Konopelko et al. 2008). These plutonic rocks, which are $>30 \mathrm{~m}$.yr. older than the MiddleLate Paleozoic Yili Arc magmatic rocks, probably resulted from Early Paleozoic northward subduction of the "Kyrgyz-Terskey Ocean" beneath the Yili Block (Yang et al. 2006; Konopelko et al. 2008; Gao et al. 2009; Qian et al. 2009).

Precambrian Substrata. The arc-related volcanic rocks and associated sedimentary rocks unconformably overlie or are in fault contact with Sinian (Neoproterozoic) stromatolitic dolomite, limestone, and orthogneiss, Mesoproterozoic metasediments, and migmatites of probable Paleoproterozoic age (fig. 2; XBGMR 1993). The orthogneisses developed along the Nalati Fault were dated at $707 \pm 13$ and $882 \pm 33 \mathrm{Ma}$ (zircon U-Pb; Chen et al. $2000 a, 2000 b$ ). The metasediments occurring to the south of the Nalati Fault (fig. 2) consist of mar- 


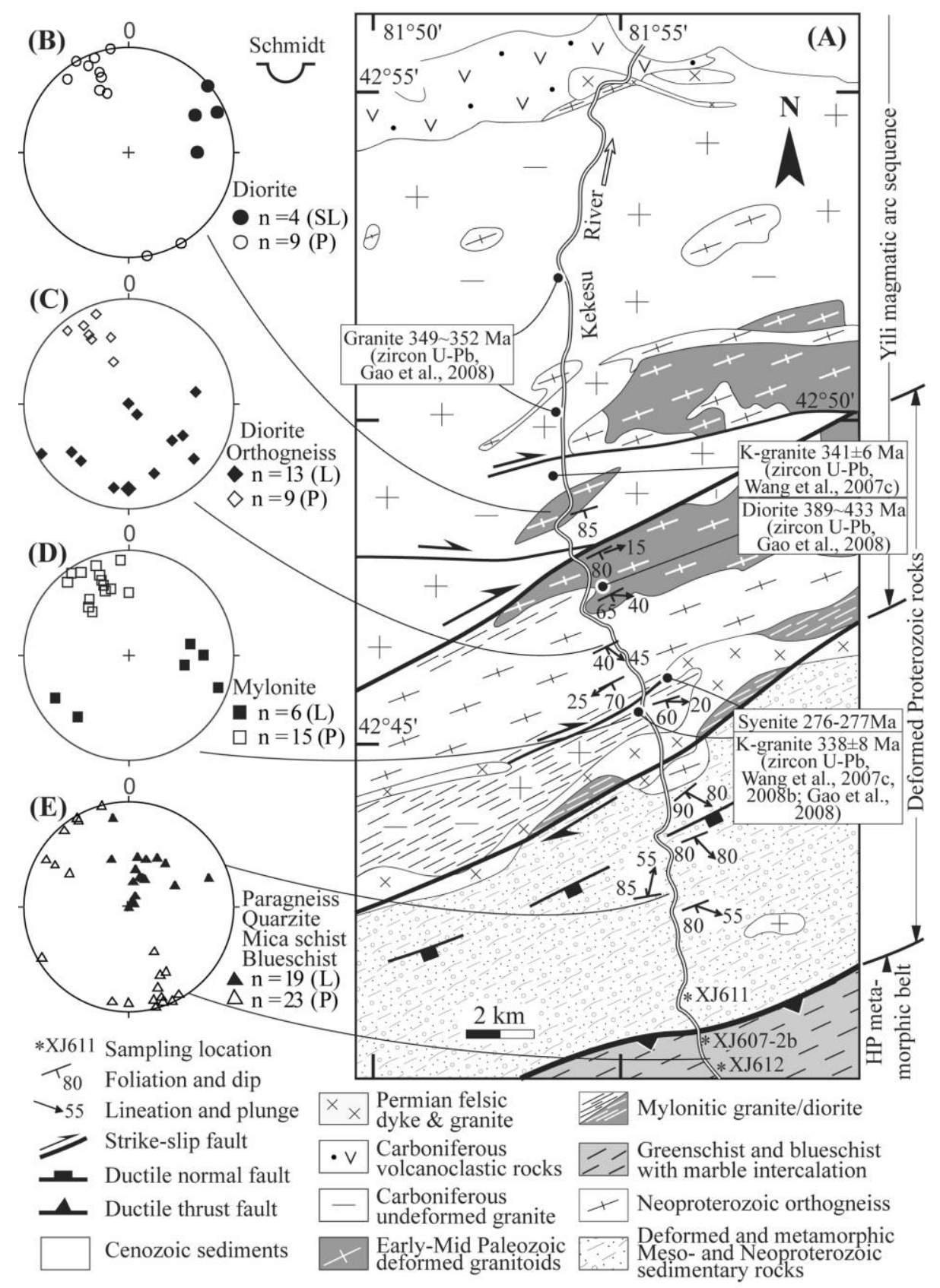

Figure 3. A, Structural map of the Kekesu section (modified from XBGMR 1979; Gao 2000). B-E, Lower-hemisphere Schmidt plots of the planar and linear elements. $B$, Vertical brittle faults $(P)$ and subhorizontal slickensides $(S L)$ related to brittle dextral shearing. $C$, Subvertical to SE-dipping foliation $(P)$ bearing scattered stretching lineation $(L)$; the average northwest-southeast plunge is associated with top-to-the-northwest shearing. $D$, Subvertical foliation and subhorizontal lineation related to a dextral wrenching along the Nalati Fault zone. E, Subvertical foliation and lineation. Most of the lineations are developed during a top-to-the-north shearing. However, some shear criteria locally developed in quartzite and quartz-rich micaschist indicate a normal fault geometry. 
ble, micaceous quartzite, sillimanite-cordierite micaschist, biotite gneiss, and garnet-plagioclase granulite (Gao et al. 1995). The age of these hightemperature metamorphic rocks was estimated at 910 (Sm-Nd) to $1400 \mathrm{Ma}$ (Rb-Sr; Gao et al. 1995).

The Precambrian substrata are comparable to those in the northern Yili Block (fig. 1C), where the orthogneisses were dated at $798 \pm 8$ to $821 \pm 11$ $\mathrm{Ma}$ by the zircon U-Pb method and at 759-901 Ma by the whole-rock $\mathrm{Rb}$-Sr isochron method ( $\mathrm{Hu}$ et al. 1998, 2001; Chen et al. 1999b). These granitic rocks yielded $\mathrm{Nd}$ depleted-mantle model ages ranging from 1.38 to $2.01 \mathrm{Ga}$, suggesting the existence of a Paleoproterozoic basement for the Yili Block (Chen et al. 1999b; Hu et al. 2000).

Permian Synkinematic Plutons. Within the Nalati Fault zone, pink porphyritic granite and syenite intrude the Proterozoic metamorphic rocks and $\mathrm{Pa}$ leozoic arc-type granitoids (figs. 2, 3). They occur either as massive intrusions or, more often, as dikes overprinted by ductile deformation. Two plutons in this section have been dated at $277 \pm 3$ and $276 \pm 2 \mathrm{Ma}$ (zircon U-Pb LA-ICPMS; Gao et al. 2009; Wang et al. 2009). The geochemistry of these Permian granitoids indicates that they are alkaline, high-K calc-alkaline or transitional series and are probably associated with postcollisional lithosphere-scale transcurrent shearing along the Nalati Fault zone (Wang et al. 2009).

Blueschist- and Eclogite-Facies Metamorphic Complex. To the south of the Nalati Fault, blueschistand eclogite-facies metamorphic rocks form a belt more than $200 \mathrm{~km}$ long and ca. $20 \mathrm{~km}$ wide (figs. 1, 2). According to previous work (Gao et al. 1995; Gao and Klemd 2003) and our observations, the HP metamorphic belt along the Kekesu River comprises two subunits (fig. 2). The northern subunit consists of micaschists, muscovite-quartzites, greenschist, and blueschist. Eclogites are common and occur as meter-sized blocks, lenses, boudins, and thin layers within the blueschist. The blueschist is sometimes retrogressed to greenschistfacies rock. The southern subunit is composed of greenschists, quartz schists, and lenses of marble, with a few blueschist lenses but no eclogite.

The metasedimentary series of both subunits have similar protoliths, namely, pelagic argillites, siliceous shales, and chert (Gao et al. 1995). On the basis of mineralogy and trace-element geochemistry, the blueschists and eclogites are considered to have been derived from normal mid-ocean ridge or oceanic island basalts formed in oceanic ridge or seamount setting (Gao et al. 1995; Simonov et al. 2008). Therefore, the protoliths of the HP metamorphic rocks include both oceanic crustal rocks and sea-floor sediments and likely represent an oceanic basin (Gao and Klemd 2003).

According to some authors, the blueschists and eclogites have experienced prograde HP $(2.0 \pm 0.1$ $\mathrm{GPa})$ and low-temperature $\left(530^{\circ} \pm 50^{\circ} \mathrm{C}\right)$ metamorphism (Gao and Klemd 2001, 2003; Klemd et al. 2002; Klemd 2003; Lin and Enami 2006). However, others argue for much higher pressure conditions for the eclogites: 2.3-5.0 GPa (e.g., Wei et al. 2003; Zhang et al. 2003; Lü et al. 2008; Simonov et al. 2008). In the Kekesu Section, the blueschist-facies metamorphism was overprinted by a greenschistfacies event during a nearly isothermal decompression (Gao and Klemd 2003; Klemd et al. 2005).

\section{Kinematics of Polyphase Ductile Deformation}

Most of the rocks in the Kekesu Section were variably ductilely deformed. Our structural observations suggest that the foliation strikes consistently in a northeast-southwest direction, but the different orientations of lineation and kinematic criteria allow us to distinguish three phases of deformation.

Dextral Strike-Slip Shearing. In the northern part of the Kekesu Section, Paleozoic unmetamorphosed diorite and granite form cataclastic lenses showing subvertical, N80E brittle shear planes with subhorizontally plunging slickensides (figs. $3 B, 4 A)$. Farther to the south, the $338 \pm 8$-Ma Kgranite (Wang et al. 2007c) and diorite are mylonitized. The mylonitization is localized within a 5$\mathrm{km}$-wide bifurcated zone of the Nalati Fault (fig. $3 A$ ). The northeast-southwest-striking and steeply southeast-dipping shear planes display subhorizontal stretching and mineral lineations (fig. $3 D$ ) that are marked by boudinaged pyroxenes or feldspar ribbons. Dikes of Permian K-feldspar granite and syenite intrude the mylonite. Some dikes are folded with axial planes parallel to the foliation, and other dikes are boudinaged within the foliation (fig. $4 B$, 4C).

On the $X-Z$ plane of the strain ellipsoid, that is, in sections perpendicular to the foliation and parallel with the lineation, drag folds and asymmetric boudins indicate a dextral sense of shear (fig. $4 D$, $4 E)$. At the microscopic scale, the most representative shear criteria are sigma- and delta-type porphyroclasts of feldspar or pyroxene, sigmoidal mica fish, biotite pressure shadows around clasts, and elongated quartz ribbons with an oblique-shaped fabric of recrystallized grains (fig. $4 F-4 H$ ).

Top-to-the-North Thrusting. Between the strikeslip shear zones, the foliation in Neoproterozoic orthogneiss dips gently to the southeast (fig. 3A). On the foliation surface, K-feldspar clasts and bi- 

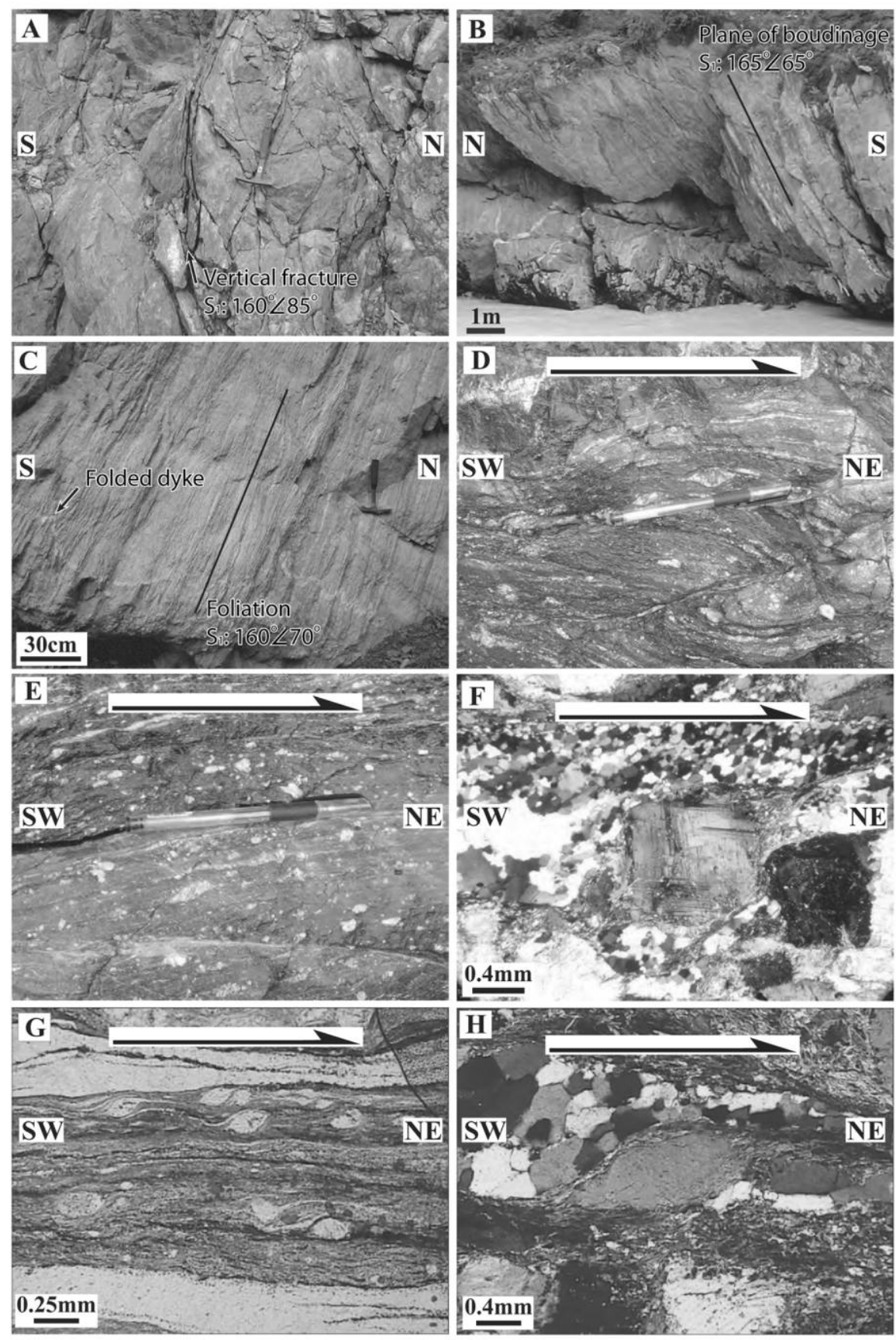

Figure 4. Photographs and photomicrographs of the structures associated with dextral shearing along the Nalati Fault. A, Cataclastic diorite, showing the lensoid fabric due to vertical brittle fractures; these surfaces exhibit subhorizontal slickensides. $B$, Boudinaged and sheared diorite intruded by syenite or pink K-granitic dikes; both diorite and dikes are foliated and protomylonitized by dextral wrenching. $C$, Folded granitic dike in foliated diorite, accounting for shortening perpendicular to the foliation. $D$, Mylonite with drag folds and asymmetric feldspar clasts showing dextral shearing. E, Mylonite with sigma-type feldspar clasts. F, Thin section perpendicular to the foliation and parallel to the lineation of a mylonitic granite: sigma-type feldspar clasts and recrystallized quartz grains with an obliqueshaped fabric. G, Ultramylonite with sigma- and delta-type clasts, showing dextral sense of shear. $H$, Foliated diorite, showing mica fish and quartz recrystallization fabrics. A color version of this figure is available in the online edition or from the Journal of Geology office. 
otite clots form mineral lineation that plunges mostly toward the southeast and also commonly toward south or southwest (figs. 3C, 5A). The pitch of lineation varies from $25^{\circ}$ to $65^{\circ}$, and closer to the shear zones, the steeper the foliation the shallower the pitch of the lineation (fig. 3A). This suggests that the scattering of lineation resulted from local rotation by dextral strike-slip movement and that the original orientation of lineation should be southeast, correlating with a northwest-southeast stress. Similar planar and linear structures can be recognized in the Early Paleozoic diorite (figs. $3 A$, $3 C, 5 B)$, although variably mylonitized by strikeslip shearing, but they cannot be observed in the mylonitic K-granite of $338 \mathrm{Ma}$ (fig. 3A; Wang et al. 2007c). In the Mesoproterozoic micaschists, muscovite-bearing quartzite, and biotite gneiss, foliation is steeply dipping to the southeast (fig. $3 E$ ) and contains a down-dip stretching lineation. Asymmetric plagioclase porphyroclasts and microscopic-
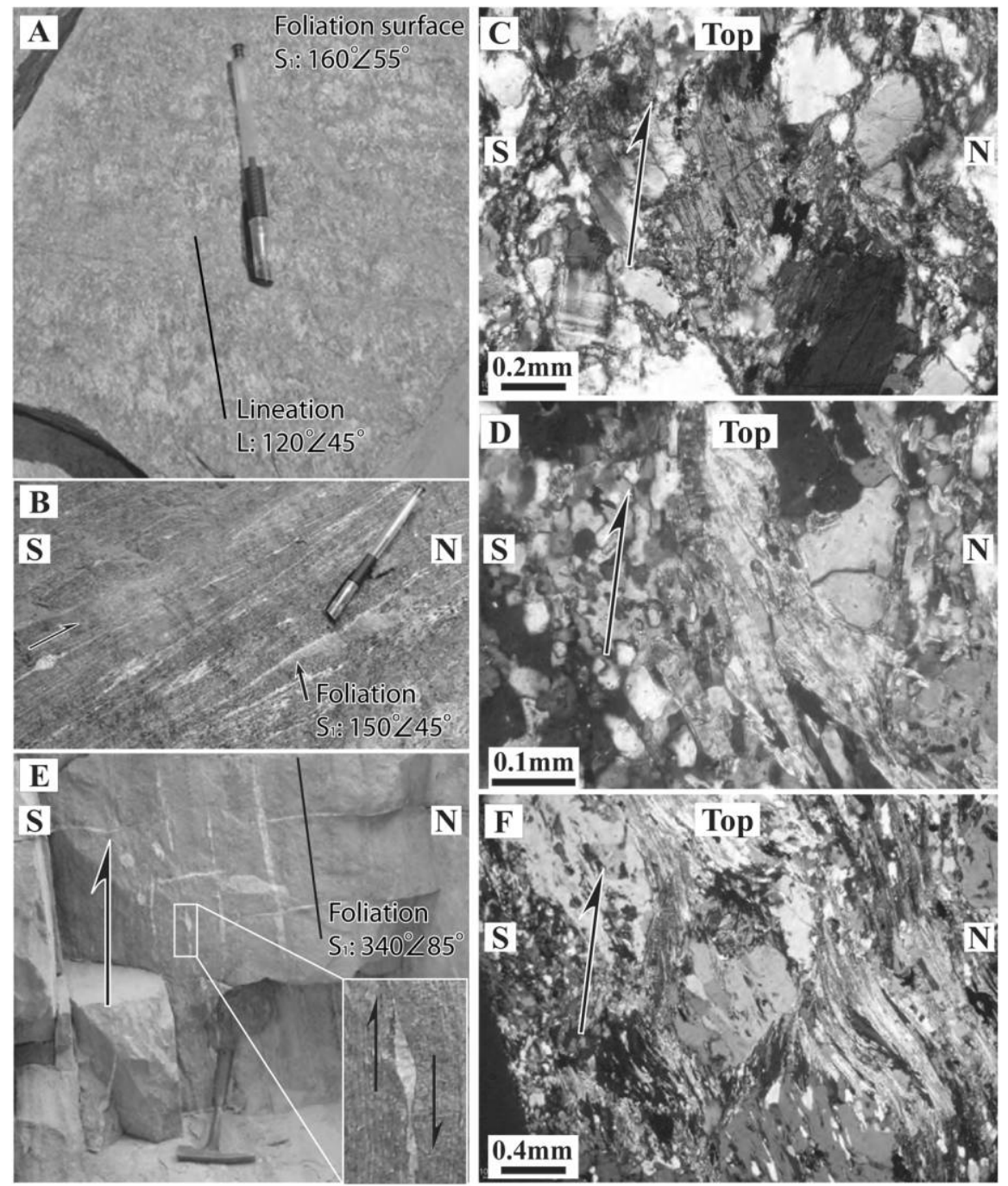

Figure 5. Field photographs and photomicrographs of deformation features associated with north-directed thrusting. $A$, Orthogneiss with mineral lineation steeply plunging to the southeast. $B$, Mylonitic diorite, showing gentle foliation and sigmoidal feldspar indicating top-to-the-north shearing. $C, D$, Sigmoidal amphibole in diorite $(C)$ and muscovite shear bands in micaschist $(D)$, showing a top-to-the-north shearing. E, Greenschist-facies siliceous sandstone with quartz veins parallel to the foliation. The asymmetric shape of the boudins indicates a top-to-the-north movement. The tension gashes perpendicular to the foliation are postfolial structures, but the geometry agrees with a subhorizontal compression. F, Muscovite-albite micaschist with top-to-the-north shear bands. A color version of this figure is available in the online edition or from the Journal of Geology office. 
scale sheared amphibole of mylonitic diorite (fig. $5 B, 5 C)$ and shear bands of muscovite from micaschist (fig. $5 D$ ) consistently show a top-to-thenorth sense of shear.

The HP metamorphic complex is in contact with the metamorphosed and deformed Proterozoic metasediments along a steeply south-dipping ductile thrust fault. Within the HP metamorphic complex, albite-biotite micaschist and quartzite are characterized by a northeast-southwest-striking, steeply dipping foliation bearing a subvertical stretching lineation (fig. 3E). Intrafolial rootless tight folds with axes parallel with the lineation are indicative of intense progressive deformation. Sigmoidal quartz veins parallel to the foliation indicate top-to-the-north movement (fig. 5E). In thin section, the micaschists contain asymmetric albite porphyroblasts with biotite pressure shadows that also show a top-to-the-north shearing (fig. 5F).

South-Directed Shearing. In the northern and central parts of the highly deformed and metamorphosed Mesoproterozoic sedimentary rocks (fig. $3 A$ ), the subvertical foliation is deformed by open folds with flat-lying axial planes sometimes associated with a subhorizontal crenulation cleavage (fig. 6A), indicating a vertical shortening. This de- formation is recognized only in a $<500$-m-wide zone (fig. 3A). In thin section cut parallel to $X-Z$ plane, sigmoidal muscovite and recrystallized quartz ribbons with an oblique grain-shaped fabric indicate a top-to-the-south shearing. In the present geometry, this kinematics corresponds to a southward-directed movement at the southern side (fig. $6 B, 6 C)$.

The contact between the HP metamorphic belt and the Ordovician-Silurian nonmetamorphic series to the south is currently dominated by a steeply south-dipping reverse fault (fig. 2); however, the HP metamorphic rocks in the footwall of this fault were mylonitized. It is therefore inferred to have been a south-directed normal-sense-of-shear zone, although it was considered a ductile thrust by Gao et al. (1995) and Lin et al. (2009).

\section{New ${ }^{40} \mathrm{Ar} /{ }^{39} \mathrm{Ar}$ Dating of High-Pressure Metamorphic Rocks}

Previous Isotopic Ages. Gao et al. (1995) obtained a ${ }^{40} \mathrm{Ar} /{ }^{39} \mathrm{Ar}$ plateau age of $346 \pm 7 \mathrm{Ma}$ on phengite of the Kekesu blueschist. From the Changawuzi blueschist (fig. $1 B$ ), glaucophane yielded a ${ }^{40} \mathrm{Ar} /{ }^{39} \mathrm{Ar}$ age of $351 \pm 2 \mathrm{Ma}$ (Xiao et al. 1992); in the same
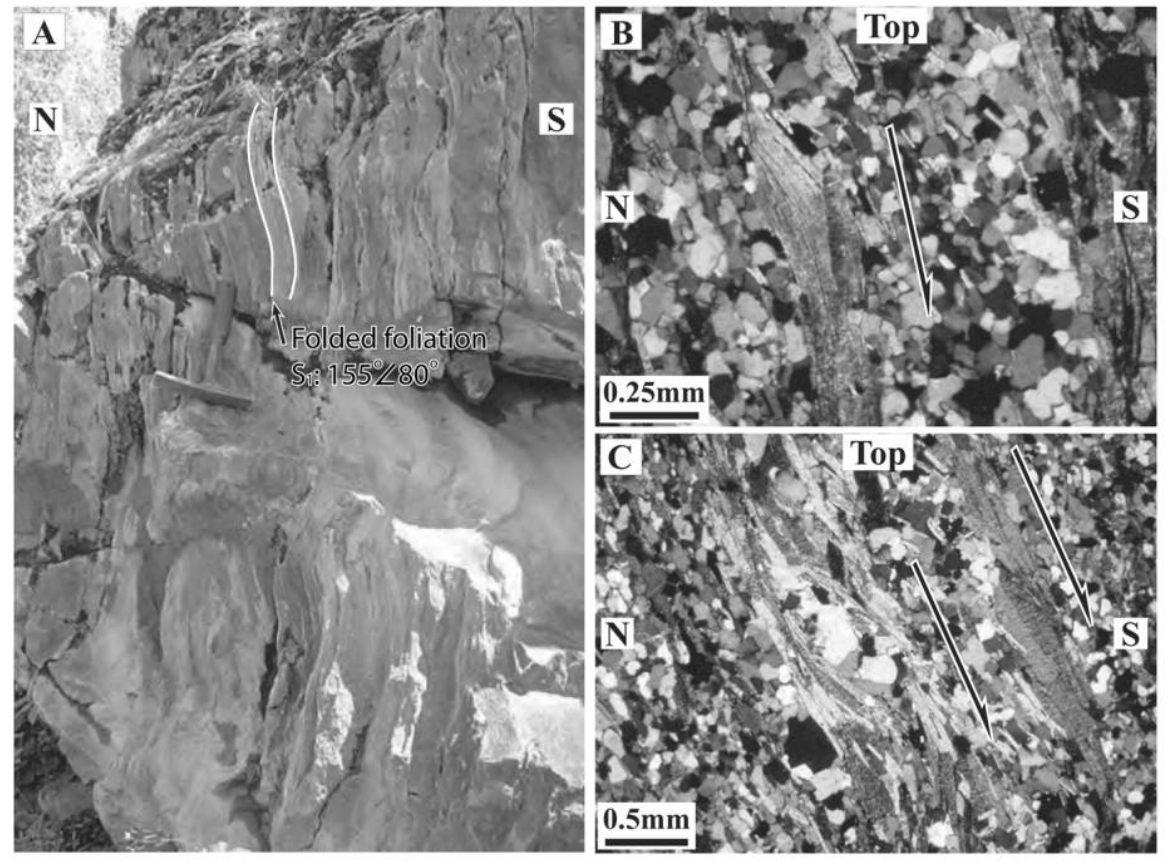

Figure 6. Field photographs and photomicrographs of structures related to south-directed normal shearing. $A$, Quartzrich micaschist with a folded vertical foliation; the subhorizontal axial planes argue for a vertical shortening. $B, C$, Sigmoidal muscovite and recrystallized quartz ribbons, showing a top-to-the-south ductile shearing interpreted as normal faulting. A color version of this figure is available in the online edition or from the Journal of Geology office. 
area, an eclogite yielded $\mathrm{Sm}-\mathrm{Nd}$ isochron ages of $343 \pm 44$ (Omp-Grt-Gln-WR [whole rock]) and $346 \pm 3 \mathrm{Ma}$ (Grt-Gln) and ${ }^{40} \mathrm{Ar} /{ }^{39} \mathrm{Ar}$ plateau ages of $344 \pm 1$ (crossite) and $345 \pm 1 \mathrm{Ma}$ (glaucophane; Gao and Klemd 2003; Gao et al. 2006). Consequently, the age of $\sim 345 \mathrm{Ma}$ was regarded as the best estimate for the timing of the eclogite-facies metamorphism in the Southern Tianshan /Gao and Klemd 2003).

The HP metamorphic rocks of the Southern Tianshan have yielded older isotopic ages. Phengites from blueschists occurring in the south of Qiongkushitai (fig. 2) yielded a dome-shaped ${ }^{40} \mathrm{Ar} /$ ${ }^{39} \mathrm{Ar}$ age spectrum, the top of which yielded an age of $415 \pm 2 \mathrm{Ma}$ (Gao 1993). In Akeyazi (fig. 1B), Gao et al. (2000) obtained ${ }^{40} \mathrm{Ar} /{ }^{39} \mathrm{Ar}$ plateau ages of $401 \pm 1$ (sodic amphibole) and $381 \pm 1 \mathrm{Ma}$ (phengite) from the rim of an eclogite body and ages of $370 \pm 1$ (sodic amphibole) and $364 \pm 1 \mathrm{Ma}$ (phengite) from its blueschist-facies matrix. Dobretsov et al. (1987) obtained whole-rock K-Ar ages of about 410 and $350 \mathrm{Ma}$ on the Atbashy blueschists (fig. $1 B$ ), which were dated at $267 \pm 5 \mathrm{Ma}$ (Omp-GrtPhg-WR, Rb-Sr isochron) by Tagiri et al. (1995).

These older ages may indicate a metamorphism related to an earlier stage of subduction and accretion. However, some of these ages are probably not reliable. Klemd et al. (2005) suggested that the ${ }^{40} \mathrm{Ar} /$ ${ }^{39} \mathrm{Ar}$ ages ranging from 401 to $364 \mathrm{Ma}$ obtained by Gao et al. (2000) were due to excess Ar incorporation. The K-Ar age of $410 \pm 15 \mathrm{Ma}$ from the Atbashy Belt (Dobretsov et al. 1987) is probably due to the multimineral character inherent in wholerock samples. The eclogite-facies metamorphism related to collision thus appears to have occurred at $\sim 345 \mathrm{Ma}$ (Gao and Klemd 2003). It must be mentioned that the epidote blueschist-facies metamorphism is regarded as a retrograde stage $\left(500^{\circ}-530^{\circ} \mathrm{C}\right.$, 1.0-1.2 GPa) with respect to an earlier UHP eclogite-facies event $\left(570^{\circ}-630^{\circ} \mathrm{C}, 2.6-3.3 \mathrm{GPa}\right.$; e.g., Zhang et al. 2003; Lü et al. 2008). Although this view is contested by Klemd (2003), it cannot be excluded that the UHP metamorphism in the Southern Tianshan occurred earlier than $350 \mathrm{Ma}$.

Moreover, Gao and Klemd (2003) obtained a ${ }^{40} \mathrm{Ar} /$ ${ }^{39} \mathrm{Ar}$ plateau age of $331 \pm 2 \mathrm{Ma}$ for phengite from a Changawuzi eclogite. This age was interpreted as the time when the HP rocks cooled below the effective closure temperature of phengite. Klemd et al. (2005) obtained ages of 313-302 (Rb-Sr) and 311$312 \mathrm{Ma}\left({ }^{40} \mathrm{Ar} /{ }^{39} \mathrm{Ar}\right)$ for phengite and/or paragonite from blueschist-facies rocks that formed during or after the transition from eclogite-facies to epidoteblueschist-facies conditions and subsequently experienced an incipient greenschist-facies overprint.
The Atbashy eclogite has yielded comparable ${ }^{40} \mathrm{Ar} /$ ${ }^{39} \mathrm{Ar}$ plateau ages of $327 \pm 4$ to $324 \pm 4 \mathrm{Ma}$ for phengites and $324 \pm 10 \mathrm{Ma}$ for glaucophane (Stupakov et al. 2004; Simonov et al. 2008).

On the other hand, Zhang et al. (2007) obtained SHRIMP U-Pb ages of $233 \pm 4$ and $226 \pm 5 \mathrm{Ma}$ on rims of zircon from the eclogites and metapelites at Changawuzi (fig. $1 B$ ). Li et al. $(2005,2007)$ reported single-grain ${ }^{206} \mathrm{~Pb} /{ }^{238} \mathrm{U}$ ages of ca. $290-280$ $\mathrm{Ma}$ from unzoned zircon crystals and jagged microfractures of much older zircons of the eclogites. Zhang et al. (2007) suggested that the zircon rim ages of 233-226 Ma correspond to collision-related HP metamorphism. In contrast, others (Gao et al. 2006; Li et al. 2008) argued that these young nocore zircons formed through fluid-assisted recrystallization; this point of view is supported by differential variation of $U$ and $T h$ compositions in zircons lacking cores (Rowley et al. 1997). The similar age given by Tagiri et al. (1995) was also probably influenced by effects of later fluid event (de Jong et al. 2009).

Sample Description. In order to establish additional age constraints, two partially retrogressed blueschists (XJ607-2b and XJ612) were taken from the lowest part of the blueschist unit, and one greenschist (XJ611) was sampled from the southernmost part of the metasedimentary cover of the Yili Block, which is overthrust by the blueschist unit (fig. $3 A$; see table $\mathrm{A} 1$, available in the online edition or from the Journal of Geology office, for GPS).

Sample XJ607-2b is a foliated and lineated garnetbearing blueschist that contains substantial amounts of chlorite and white mica (fig. $7 A$ ). Variation in the modal composition of oriented blue amphibole and epidote defines a layering at a scale of several millimeters. Amphibole occurs as $~ 1$ mm-long crystals that often form aggregates with the same orientation. The amphibole crystals show a distinctive deep blue to pale violet pleochroism, and they are strongly zoned, usually with deep blue cores and lighter shades in rims, and show a uniform dark blue to purple color when included in garnet. The lighter-colored rims are intergrown with or replaced by chlorite that occurs between pulled-apart albite crystals. White mica generally occurs in chlorite-rich layers that contain relics of blue amphibole, as individual crystals or as aggregates with a decussate structure. White mica and chlorite may be intergrown along their basal cleavages; these tabular strain-free crystals are 500-1500 $\mu \mathrm{m}$ in length. Undeformed white mica has locally overgrown the amphibole-rich layers.

Sample XJ612 is a lineated blueschist with a prin- 

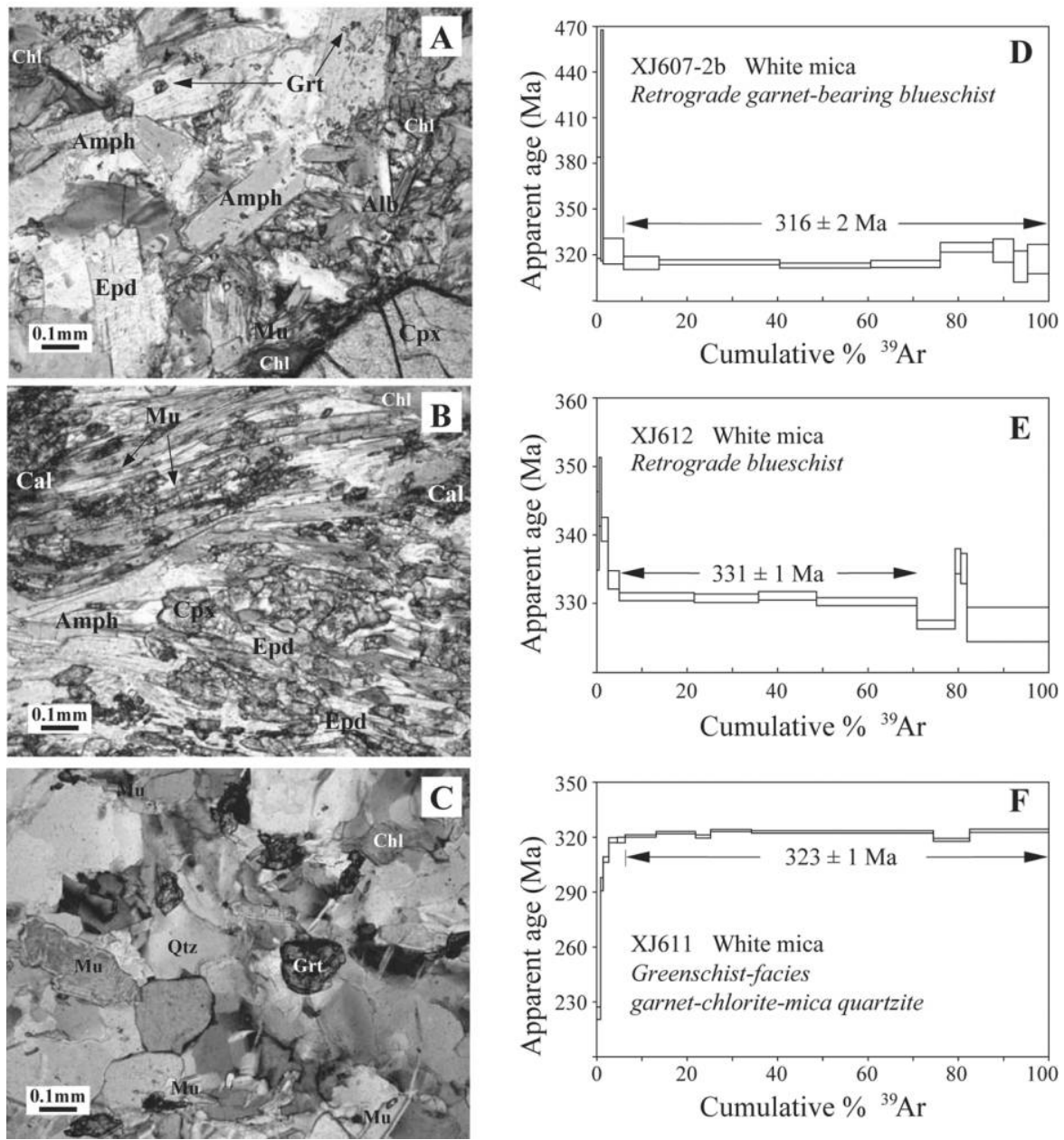

Figure 7. Photomicrographs and ${ }^{40} \mathrm{Ar} /{ }^{39} \mathrm{Ar}$ age spectra acquired by laser step-heating of single white mica grains from retrogressed blueschists and greenschist-facies quartzite from the Kekesu Section. Errors are reported at the $1 \sigma$ level. $A l b=$ albite,$A m p h=$ amphibole, $C a l=$ calcite, $C h l=$ chlorite,$C p x=$ clinopyroxene, Epd = epidote, $G r t=$ garnet, $M u=$ muscovite, and $Q t z=$ quartz. A color version of this figure is available in the online edition or from the Journal of Geology office.

cipal foliation defined by difference in modal composition of oriented blue amphibole and epidote, along which green chlorite and white mica have grown (fig. $7 B$ ). The foliation curves around porphyroclasts of metamorphic clinopyroxene that contains inclusions of glaucophane displaying an orientation parallel to the external foliation. The principal foliation is cut by slightly deformed tension gashes filled with carbonate. Blue amphibole crystals $(\sim 1 \mathrm{~mm}$ long) are moderately zoned, with darker cores and lighter rims. The amphibole is overgrown and replaced by both chlorite and albite. White mica (150-1500 $\mu \mathrm{m}$ long) generally occurs parallel to the main foliation and is in part intergrown with chlorite along their basal cleavages. Undeformed crystals and aggregates of intergrown chlorite and white mica cross-cut the amphibolerich layers occasionally.

Sample XJ611 is an inequigranular garnet-bearing chlorite-mica quartzite with ill-defined foliation (fig. $7 C$ ). Equidimensional quartz crystals reveal a moderate dynamic recrystallization, mainly by sutured boundaries and development of subgrains. White mica is present as $100-1000-\mu \mathrm{m}$-long, strainfree crystals in the quartz matrix. These white micas have occasionally grown along the basal cleavages of chlorite porphyroblasts. Abundant garnet is devoid of glaucophane inclusions. Minor carbonate occurs as large crystals that overgrow the matrix.

${ }^{40} \mathrm{Ar} /{ }^{39} \mathrm{Ar}$ Dating Technique and Results. White mica minerals were handpicked under a binocular zoom microscope from the $0.3-2-\mathrm{mm}$ size fraction 
of the crushed rocks. The subsequent treatment and analyses were performed in the Geosciences Laboratory of Rennes I University (France). The samples were wrapped in Al foil envelopes (11 $\mathrm{mm} \times 11 \mathrm{~mm} \times 0.5 \mathrm{~mm}$ ), which were stacked in an irradiation can, with flux monitors /standard sanidine TCR-2, with an age of $28.34 \pm 0.32 \mathrm{Ma}$; Renne et al. 1998) inserted after every 8-10 samples. The sample arrangement allowed us to monitor the flux gradient with a precision of $\pm 0.2 \%$. Samples and standards were irradiated for $13.33 \mathrm{~h}$ at the McMaster reactor (Hamilton, Ontario, Canada) with a total flux of $1.7 \times 10^{18} \mathrm{n} \mathrm{cm}^{-2}$. Single grains of white mica were analyzed by incremental heating with a ${ }^{40} \mathrm{Ar} /{ }^{39} \mathrm{Ar}$ laser probe $\left(\mathrm{CO}_{2}\right.$ Synrad). The step-heating experimental procedure has been described in detail by Ruffet et al. (1991, 1995). Blanks are routinely conducted at the start of an experiment, typically repeated after each third step, and subtracted from the subsequent sample gas fractions. Analyses were completed on a MAP215 mass spectrometer.

Plateau ages were calculated if $70 \%$ or more of the ${ }^{39} \mathrm{Ar}_{\mathrm{K}}$ was released in three or more contiguous steps, the apparent ${ }^{40} \mathrm{Ar}^{*} /{ }^{39} \mathrm{Ar}_{\mathrm{K}}$ ages of which agreed within $1 \sigma$ with the integrated age of the plateau segment. Pseudoplateau ages meet these criteria for segments for which less than $70 \%$ of the ${ }^{39} \mathrm{Ar}$ was released. The ${ }^{40} \mathrm{Ar} /{ }^{39} \mathrm{Ar}$ analytical data are listed in table A1 and are portrayed as age spectra in figure $7 D-7 F$. All errors are quoted at $1 \sigma$ level.

White mica from strongly retrogressed blueschist (XJ607-2b) yielded a plateau age of $316 \pm 2 \mathrm{Ma}$ $\left(94.1 \%\right.$ of ${ }^{39} \mathrm{Ar}_{\mathrm{K}}$ released; fig. $\left.7 D\right)$, whereas white mica from a moderately retrogressed blueschist (XJ612) yielded a pseudoplateau age of $331 \pm 1 \mathrm{Ma}$ $\left(65.9 \%\right.$ of ${ }^{39} \mathrm{Ar}_{\mathrm{K}}$ released; fig. $\left.7 E\right)$. White mica in greenschist-facies metamorphic quartzite XJ611 gave a plateau age of $323 \pm 1 \mathrm{Ma}\left(93.7 \%\right.$ of ${ }^{39} \mathrm{Ar}_{\mathrm{K}}$ released; fig. $7 F)$.

\section{Discussion}

In the following, the significance of new ${ }^{40} \mathrm{Ar} /{ }^{39} \mathrm{Ar}$ isotopic ages, three ductile deformation events, and their tectonic implications are discussed. The deformation and metamorphic events are presented in reverse order in order to remove the overprints of the younger events on the earlier ones.

Interpretation of New ${ }^{40} \mathrm{Ar} /{ }^{39} \mathrm{Ar}$ Ages. The 331316-Ma ${ }^{40} \mathrm{Ar} /{ }^{39} \mathrm{Ar} \mathrm{K}$-white mica ages that were obtained from partially retrogressed HP metamorphic rocks are much younger than the age of the eclogite-facies metamorphism ( 345 $\mathrm{Ma}$; $\mathrm{Gao}$ and Klemd 2003). These new data are comparable to the phengite ${ }^{40} \mathrm{Ar} /{ }^{39} \mathrm{Ar}$ plateau age of $331 \pm 2 \mathrm{Ma}$ that was interpreted as the time constraining the exhumation of the HP metamorphic rocks (Gao and Klemd 2003). The retrograde mineralogy (characterized by abundant late-stage chlorite and albite growth) and textural relationships (intergrown mica-chlorite overgrowing the main foliation) both imply that white mica grains in samples XJ607-2b and XJ612 were formed during retrogression of the blueschist-facies metamorphic assemblage. The most strongly retrogressed blueschist (XJ607-2b) has the youngest apparent age (down to $313 \pm 2$ $\mathrm{Ma}$; fig. $7 D$; table A1). The less retrogressed blueschist (XJ612) shows evidence of disturbance of the isotopic system (cf. high-temperature apparent ages as young as ca. $326 \mathrm{Ma}$; table A1), although it yields a plateau age of $331 \pm 1 \mathrm{Ma}$.

Muscovite of retrograde blueschist XJ607-2b displays an age spectrum with a subtle saddle shape. According to Cheilletz et al. (1999) and Alexandrov et al. (2002), saddle-shaped age spectra may result from the presence of different reservoirs in the partially recrystallized mica grain with distinct argon compositions that degas over different energy intervals: a primary or inherited domain (low- and high-temperature steps) and a neo- or recrystallized one (saddle minimum in intermediate- to hightemperature steps). As suggested by Castonguay et al. (2007), the younger neo- or recrystallized subdomains could characterize the last isotopic record during a protracted (re)crystallization history. The saddle minimum at $313 \pm 2 \mathrm{Ma}$ (fig. $7 D$; table A1) could therefore correspond to the last record of the (re)crystallization history of the white mica. Muscovite of another retrograde blueschist, XJ612, displays slightly younger ages in the high-temperature steps, down to ca. $326 \mathrm{Ma}$ (fig. $7 E$; table A1), similarly suggesting a nonequilibrium state during (re)crystallization of the mineral in the course of a protracted recrystallization history or a subsequent disturbance event younger than $330 \mathrm{Ma}$.

We thus interpret the latest Early to Late Carboniferous dates as snapshots of the protracted retrograde recrystallization of the blueschist-facies mineral assemblage during exhumation. Our explanation corroborates the interpretation of Klemd et al. (2005) for the $\mathrm{K}$-white mica ${ }^{40} \mathrm{Ar} /{ }^{39} \mathrm{Ar}$ plateau and the Rb-Sr isochron ages (313-302 Ma) of the partially retrogressed blueschists. The $323 \pm 1 \mathrm{Ma}$ plateau age of white mica from greenschist-facies quartzite (XJ611) agrees well with such an age constraint and shows that Carboniferous recrystallization also affected the ductilely deformed metasedimentary cover of the crystalline basement of the southern margin of the Yili Block. 
Permian Postcollisional Dextral Wrenching. Ductile strike-slip faults form a $10 \pm 5$-km-wide shear zone in the Southern Tianshan (fig. 1B). Kinematic analysis from the Kekesu Section indicates a dextral sense of shear, consistent with observations in Akyazhi (Lin et al. 2009), the Nalati Pass (Yin and Nie 1996; Yin et al. 1998), the MTSZ (LaurentCharvet et al. 2002, 2003), and the Eastern Tianshan (Wang et al. 2008b; fig. 1). Hornblende, biotite, and feldspar from ultramylonitized or foliated granitic rocks in the Nalati Pass, the MTSZ, and the Eastern Tianshan yielded ${ }^{40} \mathrm{Ar} /{ }^{39} \mathrm{Ar}$ ages of $245-285$ Ma (Zhou et al. 2001; Laurent-Charvet et al. 2003; Wang et al. 2008b; de Jong et al. 2009).

In contrast, a sinistral motion has been proposed for the Nikolaev Line (Mikolaichuk et al. 1995; Bazhenov et al. 1999), but its age remains poorly constrained. To the north of Kumux, a sinistral sense of shear was recognized; muscovite and biotite from mylonite yielded ill-defined ${ }^{40} \mathrm{Ar} /{ }^{39} \mathrm{Ar}$ plateau ages from $393 \pm 6$ to $367 \pm 2 \mathrm{Ma}$ (Deng et al. 2006). Sinistral shear criteria are also preserved along the MTSZ (Laurent-Charvet et al. 2003) and in the Kekesu Section (Gao et al. 1995) and were interpreted as an earlier stage of strike-slip shearing (Shu et al. 1999; Wang et al. 2008b).

Therefore, although a sinistral sense of shearing cannot be precluded and its timing and tectonic significance are not well constrained, we conclude that the Nalati Fault and its western (Nikolaev Line) and eastern (MTSZ) extensions form a Permian-Early Mesozoic large-scale dextral shear zone. It is coeval with the Late Permian to Triassic strikeslip system around the Junggar Basin (fig. $1 A$; Allen and Vincent 1997; Laurent-Charvet et al. 2003; Wang et al. 2006). This wrenching is considered a postcollisional intraplate event induced by the relative rotation between continental blocks (Bazhenov et al. 1999; Van der Voo et al. 2006; Wang et al. 2007a). The wrenching brought forth the eastwest extension and related emplacement of syenite and pink K-granite within or near the shear zones associated with the regional fluid activity (Wang et al. 2009). These later tectonothermal events could reset the isotopic system of the muscovite and biotite in the contiguous pre-Permian granitic rocks and metamorphic rocks (figs. 2, 3). For instance, the ${ }^{40} \mathrm{Ar} /{ }^{39} \mathrm{Ar}$ plateau age $(263 \pm 1 \mathrm{Ma})$ of the biotite granite within the Nalati Fault zone is much younger than its intrusion age $(313 \pm 4 \mathrm{Ma}$; Wang et al. 2007 c); the white mica and biotite from preCarboniferous metasediments to the south of the Nalati Fault also yielded concordant ${ }^{40} \mathrm{Ar} /{ }^{39} \mathrm{Ar}$ plateau ages of 252-253 Ma (de Jong et al. 2009).

Mid-Late Carboniferous Normal Faulting and Ex- humation of the High-Pressure Complex. Southdirected ductile shearing was observed in the greenschist-facies metasediments of the Kekesu Section. The current subvertical attitude of the foliation leads to two possible interpretations for this deformation: top-to-the-south thrusting or southdirected normal faulting. The former might correspond to the D3 deformation recognized by Gao et al. (1995) along the same section. A similar deformation was also identified in the Akeyazi Section (fig. 1; Lin et al. 2009); there, south-vergent folds and associated mineral lineation are present in cordierite-sillimanite-biotite-bearing gneiss and two-pyroxene granulite. Consequently, this deformation could be considered (1) a tilted southdirected thrust related to the north-directed subduction and subsequent collision (Gao et al. 1995, 1998) or (2) top-to-the-south (southeast) backthrusting induced by a convergent event to the north of the Yili Block (Lin et al. 2009).

However, according to available structural data and our field study, the south-directed ductile shearing is localized within a narrow zone in the metasedimentary rocks, although it can be very locally observed in blueschists. Structurally, this ductile shearing is associated with open folding that accommodated a vertical shortening, indicating a subhorizontal extension. Thus, the south-directed shearing that redeformed the preexisting foliation is likely associated with normal faulting within a decollement layer below the HP metamorphic complex. In addition, petrological and mineralogical studies suggest that this deformation was accompanied by the greenschist-facies retrogression of the blueschist and Mesoproterozoic metasediments (e.g., Gao et al. 1995). According to classical models, extensional detachment typically occurs above the HP metamorphic complex during synorogenic and postorogenic stages and leads to the removal of overburden and exhumation of HP rocks (e.g., Platt 1993; Faure et al. 1999; Parra et al. 2001). Synchronous thrusting below the HP complex may be converted into normal faulting during postorogenic extension, resulting in the continuous exhumation of both the HP rocks and underthrust continental materials (e.g., Faure et al. 1999; Jolivet et al. 2003 and references therein). The Carboniferous Yili Arc magmatism and back-arc regime may have been conducive to such an extentional setting. Therefore, the south-directed shearing is considered here to be normal faulting below the HP metamorphic complex related to the final exhumation in postorogenic times. Normal faulting contemporaneous with exhumation of the HP metamorphic rocks is inferred to have occurred along the 
mylonitic zone in the uppermost part of the HP metamorphic belt (fig. 2), but this assumption requires further testing on the basis of detailed kinematic analyses.

Our new age data and those of Klemd et al. (2005) provide an age constraint for the greenschist-facies retrogressive metamorphism at ca. 335-310 Ma. This period probably also corresponds to the time of the south-directed ductile normal faulting and related exhumation of the HP metamorphic complex. On the basis of detailed structural analysis, mineralogical study, and abundant thermochronological data, we suggest that the superposition of this ductile deformation on the previous one is localized along an extensional shear zone but that the coeval retrogression significantly overprinted the HP metamorphic complex.

Latest Devonian-Earliest Carboniferous Collision and High-Pressure Metamorphism. Top-to-the-north shearing is extensively developed in the oceaniccrust-derived HP metamorphic rocks, the underlying metasediments, and the amphibolite-facies metamorphic basement of the Yili Block as well as in the intruding Silurian-Devonian granitoids (figs. $2,3,8)$. This event is also recorded in strongly deformed but weakly to unmetamorphosed Ordovician-Silurian rocks that were thrust northward over the HP metamorphic complex (figs. 2, 8; Lin et al. 2009). This deformation is correlated with the D2 deformation of Gao et al. (1995) and Lin et al. (2009). The kinematics is consistent throughout several parallel sections.

This north-directed deformation was previously interpreted as the exhumation of the HP metamorphic rocks during a late collision stage (Gao et al. 1995, 1998) or as back-thrusting associated with the collision process (Gao and Klemd 2003). In these cases, the subduction is proposed to be northdirected (Gao et al. 1995, 1998, 2009; Mikolaichuk et al. 1997; Chen et al. 1999 $a$; Gao and Klemd 2003; Konopelko et al. 2008). An earlier D1 deformation event (Gao et al. 1995; Lin et al. 2009) is considered to have occurred during prograde HP metamorphism. The kinematics of this D1 deformation is consistent with that of the D2 top-to-the-north thrusting, which is therefore regarded as a late increment of the D1 deformation (Lin et al. 2009). These conclusions suggest a south-directed subduction (Wang et al. 2008a; Lin et al. 2009). In any case, the top-to-the-north thrusting corresponds to a contractional deformation; the prevalent occurrence of this deformation throughout the Southern Tianshan suggests that the deformation is coeval with the HP/UHP metamorphism during the subduction-collision events, that is, before the exhumation of HP rocks, although locally it may have been reworked by the synconvergent exhumation of the HP unit.

$\angle \mathbf{N}$ Yili Magmatic arc and its Proterozoic substratum
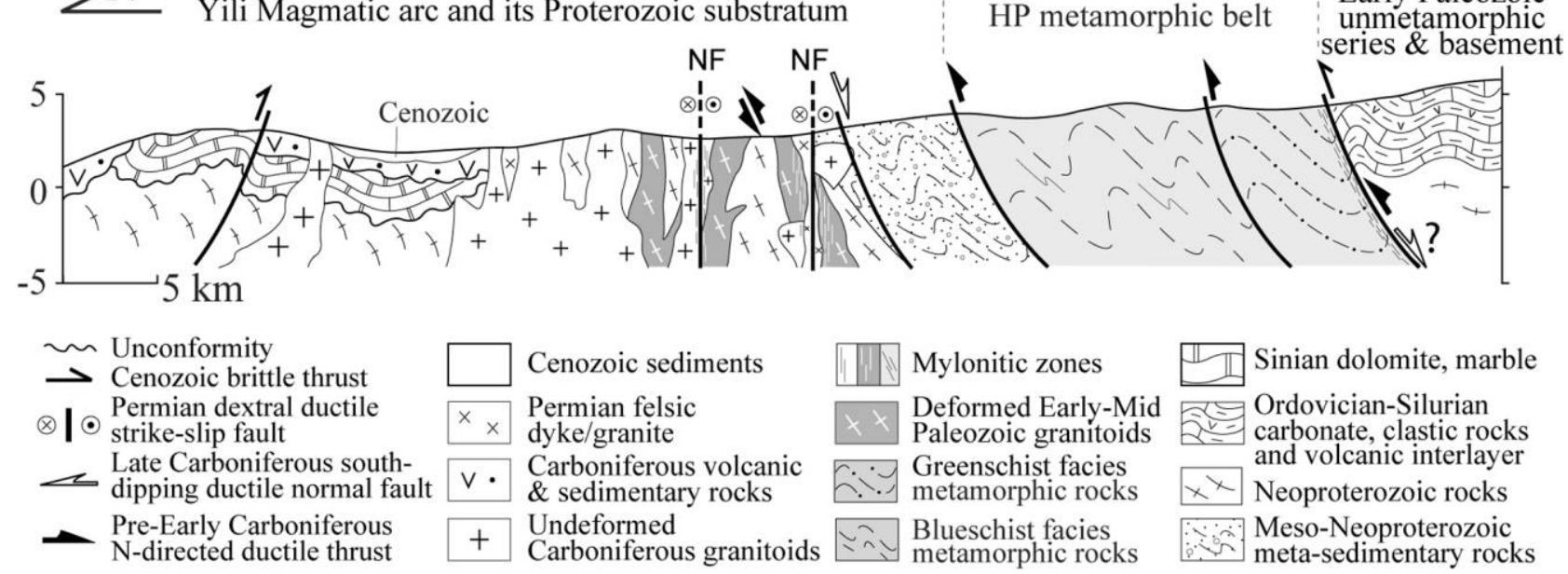

Figure 8. Interpretative cross section along the Kekesu River; location shown in figure 2. North-directed ductile thrusts correlate with synsubduction/syncollisional deformation and high-pressure (HP)/ultra-HP metamorphism; the south-directed normal fault corresponds to the postorogenic detachment and final exhumation of the HP and footwall metasedimentary rocks. The southernmost contact is, at present, an inverse fault but is supposed to have been a synsubduction/collisional thrust reactivated as a normal fault along the mylonitic zone during syn- and postorogenic exhumation of HP rocks. $N F=$ Nalati Fault. 
Many isotopic chronometers constrain the timing of the HP/UHP metamorphism to have occurred between 415 and $280 \mathrm{Ma}$. However, this deformation is difficult to date with isotopic techniques because of the extensive retrogressive metamorphism and subsequent Permian fluid activity. Putting aside all isotopic ages that could relate to excess argon, retrograde metamorphism, or late fluid infiltration, the most reliable data yield an average age of $345 \pm 10 \mathrm{Ma}$ as the best estimate for the timing of the HP/UHP metamorphism. In addition, the north-directed thrusting must postdate intrusion of the strongly deformed diorite and granodiorite (433-398 Ma) that crop out to the north of the HP metamorphic rocks (fig. $3 A$; Wang et al. 2007c; Gao et al. 2009) and must precede the formation of the K-granite (338 Ma; fig. 3A), in which the top-to-the-north thrusting is not recognized (Wang et al. 2007c). Therefore, the age of the top-to-the-north ductile thrusting is suggested to be latest Devonian to earliest Carboniferous.

Late Paleozoic Tectonics of the Southern Tianshan. On the basis of our field observations and new ${ }^{40} \mathrm{Ar} /{ }^{30} \mathrm{Ar}$ ages, combined with previous results, the collisional and postcollisional tectonic evolution of the Southern Tianshan is summarized in terms of three main stages. (1) From latest Devonian to earliest Carboniferous, continental collision occurred after the final closure of the oceanic basin; the subduction and collision led to HP/UHP metamorphism and associated top-to-the-north ductile thrusting. (2) From Mid- (335-331 Ma) to Late (316-300 Ma) Carboniferous, postcollisional extension induced south-dipping ductile normal faulting along a localized decollement layer below the HP metamorphic complex, correlating to the final stage of exhumation of the HP/UHP metamorphic rocks. The exhumation of the HP/UHP metamorphic rocks resulted in extensive retrograde metamorphism under greenschist-facies conditions. (3) Finally, in the Permian, pervasive dextral ductile strike-slip faulting developed, in agreement with regional transcurrent tectonics throughout the Tianshan Belt; the accompanying granitic intrusion and associated fluid flow severely overprinted the southern Tianshan Belt along the main ductile fault zones.

\section{Conclusions}

This study presents new structural and geochronological insights on the HP metamorphic rocks of the Southern Tianshan. Three conclusions can be drawn on the basis of comprehensive analysis of our results, in conjunction with published data.

1. Three main ductile deformation events occurred in the HP/UHP metamorphic rocks and the surrounding rocks. The first event was a top-to-thenorth thrusting related to the subduction-collision associated with HP/UHP metamorphism. The next was south-dipping normal faulting corresponding to the final exhumation of the HP/UHP metamorphic rocks in postcollisional stage. Dextral shearing then developed in response to the intraplate transcurrent tectonics.

2. The $331-316-\mathrm{Ma}{ }^{40} \mathrm{Ar} /{ }^{39} \mathrm{Ar}$ ages of white mica from retrograde blueschist- and greenschist-facies metasediments constrain the recrystallization age of the retrogressive mineral assemblage. In the light of previous results, extensive retrograde metamorphism of the HP/UHP rocks occurred as early as 335-331 Ma and lasted until 316-300 Ma. These data do not support the hypothesis of Triassic collision.

3. The Southern Tianshan accretion-collisional orogen was severely overprinted by polyphase postcollisional tectonothermal events, which therefore hampered direct isotopic dating of the initial stages of the orogeny. Isotopic age data should thus be used prudently, and basic geological evidence should be taken into account to constrain the age of the collisional event.

\section{A C K N O W LED G M EN T S}

We would like to express our gratitude to M. B. Allen and J. Gao, who helped improve the first version of the manuscript significantly. Constructive comments by two anonymous reviewers and D. Rowley are greatly appreciated. Colleagues of the Bureau of National Project 305 (Xinjiang, China) are thanked for their help during fieldwork. The Ar/Ar isotopic analysis was undertaken when K. de Jong was an associated researcher at Institute of Advanced Studies Studium (CNRS and Région Centre) while being based at l'Institut des Sciences de la Terre d'Orléans (University of Orléans, France). This study is funded by the National Basic Research Program of China $(973$ Programs 2007CB411301 and 2009CB825008) and the Scientific Research Foundation for Returned Overseas Chinese Scholars, State Education Ministry. B. Jahn acknowledges the support of the National Science Council (NSC-Taiwan) through grants NSC 962752-M-002-010-PA, NSC 96-2116-M-001-004, and NSC 97-2752-M-002-003-PA. 


\section{RE FER E N C E S C I T E D}

Alexandrov, P.; Ruffet, G.; and Cheilletz, A. 2002. Muscovite recrystallization and saddle-shaped ${ }^{40} \mathrm{Ar} /{ }^{39} \mathrm{Ar}$ age spectra: example from the Blond granite (Massif Central, France). Geochim. Cosmochim. Acta 66: 1793-1807.

Allen, M. B.; Şengör, A. M. C.; and Natal'in, B. A. 1995. Junggar, Turfan and Alakol basins as Late Permian to ?Early Triassic extensional structures in a sinistral shear zone in the Altaid orogenic collage, Central Asia. J. Geol. Soc. Lond. 152:327-338.

Allen, M. B., and Vincent, S. J. 1997. Fault reactivation in the Junggar region, northwest China: the role of basement structures during Mesozoic-Cenozoic compression. J. Geol. Soc. Lond. 154:151-155.

Allen, M. B.; Vincent, S. J.; and Wheeler, P. J. 1999. Late Cenozoic tectonics of the Kepingtage thrust zone: interactions of the Tien Shan and Tarim Basin, northwest China. Tectonics 18:639-654.

Allen, M. B.; Windley, B. F.; and Zhang, C. 1993. Paleozoic collisional tectonics and magmatism of the Chinese Tien Shan, Central Asia. Tectonophysics 220:89115.

Avouac, J. P.; Tapponnier, P.; Bai, M.; You, H.; and Wang, G. 1993. Active thrusting and folding along the northern Tien Shan and Late Cenozoic rotation of the Tarim relative to Dzungaria and Kazakhstan. J. Geophys. Res. 98:6755-6804.

Bazhenov, M. L.; Burtman, V. S.; and Dvorova, A. V. 1999. Permian paleomagnetism of the Tien Shan fold belt, Central Asia: post-collisional rotation and deformation. Tectonophysics 312:303-329.

Burchfiel, B. C.; Brown, E. T.; Deng, Q. D.; Feng, X. Y.; Li, J.; Molnar, P.; Shi, J. B.; Wu, Z. M.; and You, H. C. 1999. Crustal shortening on the margins of the Tien Shan, Xinjiang, China. Int. Geol. Rev. 41:665-700.

Castonguay, S.; Ruffet, G.; and Tremblay, A. 2007. Dating polyphase deformation across low-grade metamorphic belts: an example based on ${ }^{40} \mathrm{Ar} /{ }^{39} \mathrm{Ar}$ muscovite age constraints from the southern Quebec Appalachians, Canada. Geol. Soc. Am. Bull. 119:978-992.

Charvet, J.; Shu, L. S.; and Laurent-Charvet, S. 2007. Palaeozoic structural and geodynamic evolution of eastern Tianshan (NW China): welding of the Tarim and Junggar plates. Episodes 30:162-186.

Cheilletz, A.; Ruffet, G.; Marignac, C.; Kolli, O.; Gasquet, D.; Féraud, G.; and Bouillin, J. P. 1999. ${ }^{40} \mathrm{Ar} /{ }^{39} \mathrm{Ar}$ dating of shear zones in the Variscan basement of Greater Kabylia (Algeria). Evidence of an Eo-Alpine event at $128 \mathrm{Ma}$ (Hauterivian-Barremian boundary): geodynamic consequences. Tectonophysics 306:97-116.

Chen, C. M.; Lu, H. F.; Jia, D.; Cai, D. S.; and Wu, S. M. 1999a. Closing history of the southern Tianshan oceanic basin, western China: an oblique collisional orogeny. Tectonophysics 302:23-40.

Chen, Y. B.; Hu, A. Q.; and Zhang, G. X. 1999b. Zircon $\mathrm{U}-\mathrm{Pb}$ age and $\mathrm{Nd}-\mathrm{Sr}$ isotopic composition of granitic gneiss and its geological implications from Precambrian tectonic window of western Tianshan, NW China. Geochemica 28:515-520 (in Chinese with English abstract).

Chen, Y. B.; Hu, A. Q.; Zhang, G. X.; and Zhang, Q. F. 2000a. Precambrian basement age and characteristics of southwestern Tianshan: zircon $\mathrm{U}-\mathrm{Pb}$ geochronology and Nd-Sr istopic composition. Acta Petrol. Sin. 16: 91-98 (in Chinese with English abstract).

$2000 b$. Zircon U-Pb age of granitic gneiss on Duku highway in western Tianshan of China and its geological implications. Chin. Sci. Bull. 45:649-653.

de Jong, K.; Wang, B.; Faure, M.; Shu, L. S.; Cluzel, D.; Charvet, J.; Ruffet, G.; and Chen, Y. 2009. New ${ }^{40} \mathrm{Ar} /$ ${ }^{39} \mathrm{Ar}$ age constraints on the Late Palaeozoic tectonic evolution of the western Tianshan (Xinjiang, northwestern China), with emphasis on Permian fluid ingress. Int. J. Earth Sci. 98:1239-1258.

Deng, S. T.; Guo, Z. J.; Zhang, Z. C.; and Liao, G. H. 2006. Timing of the formation of the Sangshuyuanzi ductile shear zone in the central segment of the South Tianshan and its tectonic significance. Geol. China 33:641-647 (in Chinese with English abstract).

Dobretsov, N. L.; Coleman, R. G.; Liou, J. G.; and Maruyama, S. 1987. Blueschist belt in Asia and possible periodicity of blueschist facies metamorphism. Ofioliti 12:445-456.

Faure, M.; Lin, W.; Shu, L. S.; Sun, Y.; and Schärer, U. 1999. Tectonics of the Dabieshan (eastern China) and possible exhumation mechanism of ultra high-pressure rocks. Terra Nova 11:251-258.

Gao, J. 1993. Plate tectonics and geodynamics of the orogenesis of the southwest Tianshan. PhD thesis, Chinese Academy of Geological Sciences, Beijing, $90 \mathrm{p}$.

- 2000. Geological map of high-pressure low-temperature metamorphic belt in the western Tianshan Mountains, northwest of China. Hebei Geological Survey, scale $1: 200,000$.

Gao, J.; He, G. Q.; Li, M. S.; Xiao, X. C.; and Tang, Y. Q. 1995. The mineralogy, petrology, metamorphic PTDt trajectory and exhumation mechanism of blueschists, south Tianshan, northwestern China. Tectonophysics 250:151-168.

Gao, J., and Klemd, R. 2001. Primary fluids entrapped at blueschist to eclogite transition: evidence from the Tianshan meta-subduction complex in northwestern China. Contrib. Mineral. Petrol. 142:1-14.

2003. Formation of HP-LT rocks and their tectonic implications in the western Tianshan Orogen, NW China: geochemical and age constraints. Lithos 66:1-22.

Gao, J.; Klemd, R.; Zhang, L.; Wang, Z.; and Xiao, X. 1999. $\mathrm{P}-\mathrm{T}$ path of high pressure-low temperature rocks and tectonic implications in the western Tianshan Mountains (NW China). J. Metamorph. Geol. 17:621-636.

Gao, J.; Li, M. S.; Xiao, X. C.; Tang, Y. Q.; and He, G. Q. 
1998. Paleozoic tectonic evolution of the Tianshan Orogen, northern China. Tectonophysics 287:213231.

Gao, J.; Long, L. L.; Klemd, R.; Qian, Q.; Liu, D. Y.; Xiong, X. M.; Su, W.; Liu, W.; Wang, Y. T.; and Yang, F. Q. 2009. Tectonic evolution of the South Tianshan orogen and adjacent regions, NW China: geochemical and age constraints of granitoid rocks. Int. J. Earth Sci. 98: 1221-1238.

Gao, J.; Long, L. L.; Qian, Q.; Huang, D. Z.; Su, W.; and Klemd, R. 2006. South Tianshan: a Late Paleozoic or a Triassic orogen? Acta Petrol. Sin. 22:1049-1061 (in Chinese with English abstract).

Gao, J.; Zhang, L. F.; and Liu, S. W. 2000. The ${ }^{40} \mathrm{Ar} /{ }^{39} \mathrm{Ar}$ age record of formation and uplift of the blueschists and eclogites in the western Tianshan Mountains. Chin. Sci. Bull. 45:1047-1051.

Gong, F. H.; Li, Y. J.; Wang, Q. H.; Hu, S. L.; Huang, Z. B.; and Luo, J. C. 2003. New Ar-Ar geochronologic data of Paleozoic volcanic rocks in the western segment of Chinese southern Tianshan. Geol. J. Chin. Univ. 9: 494-498 (in Chinese with English abstract).

Hao, J., and Liu, X. H. 1993. Ophiolite mélange time and tectonic evolution model in South Tien Shan area. Sci. Geol. Sin. 28:93-95 (in Chinese with English abstract).

Hu, A. Q.; Jahn, B.-M.; Zhang, G. X.; Chen, Y. B.; and Zhang, Q. F. 2000. Crustal evolution and Phanerozoic crustal growth in northern Xinjiang: $\mathrm{Nd}$ isotopic evidence. Part I. Isotopic characterization of basement rocks. Tectonophysics 328:15-51.

Hu, A. Q.; Zhang, G. X.; Chen, Y. B.; and Zhang, Q. F. 2001. A model of division of the continental crustal basement and the time scales of the major geological events in the Xinjiang: based on studies of isotopic geochronology and geochemistry. Xinjiang Geol. 19: 12-19 (in Chinese with English abstract).

Hu, A. Q.; Zhang, G. X.; Zhang, Q. F.; and Chen, Y. B. 1998. Constraints on the age of basement and crustal growth in the Tianshan Orogen by $\mathrm{Nd}$ isotopic composition. Sci. China D 41:648-657.

Jahn, B.-M. 2004. The Central Asia Orogenic Belt and growth of the continental crust in the Phanerozoic. In Malpas, J.; Fletcher, C. J. N.; Ali, J. R.; and Aitchison, J. C., eds. Aspects of the tectonic evolution of China. Geol. Soc. Lond. Spec. Publ. 226:73-100.

Jahn, B.-M.; Griffin, W. L.; and Windley, B. F. 2000. Continental growth in the Phanerozoic: evidence from Central Asia. Tectonophysics 328:1-227.

Jiang, C. Y.; Wu, W. K.; Zhang, X. R.; and Cui, S. S. 1995. The change from island arc to rift valley: evidence from volcanic rocks of Awulale area. Acta Petrol. Mineral. 14:289-300 (in Chinese with English abstract).

Jolivet, L.; Faccenna, C.; Goffe, B.; Burov, E.; and Agard, P. 2003. Subduction tectonics and exhumation of highpressure metamorphic rocks in the Mediterranean orogens. Am. J. Sci. 303:353-409.

Klemd, R. 2003. Ultrahigh-pressure metamorphism in eclogites from the western Tianshan high-pressure belt (Xinjiang, western China): comment. Am. Mineral. 88:1153-1156.
Klemd, R.; Bröcker, M.; Hacker, B. R.; Gao, J.; Gans, P.; and Wemmer, K. 2005. New age constraints on the metamorphic evolution of the high-pressure/low-temperature belt in the western Tianshan Mountains, NW China. J. Geol. 113:157-168.

Klemd, R.; Schröter, F.; Will, T. M.; and Gao, J. 2002. P$\mathrm{T}$ evolution of glaucophane-clinozoisite bearing HPLT rocks in the western Tianshan orogen, NW China. J. Metamorph. Geol. 20:239-254.

Konopelko, D.; Biske, G.; Seltmann, R.; Kiseleva, M.; Matukov, D.; and Sergeev, S. 2008. Deciphering Caledonian events: timing and geochemistry of the Caledonian magmatic arc in the Kyrgyz Tien Shan. J. Asian Earth Sci. 32:131-141.

Laurent-Charvet, S.; Charvet, J.; Monié, P.; and Shu, L. S. 2003. Late Paleozoic strike-slip shear zones in eastern Central Asia (NW China): new structural and geochronological data. Tectonics 22:1099-1101.

Laurent-Charvet, S.; Charvet, J.; Shu, L. S.; Ma, R. S.; and Lu, H. F. 2002. Palaeozoic late collisional strike-slip deformations in Tianshan and Altay, eastern Xinjiang, NW China. Terra Nova 14:249-256.

Li, Q. G.; Liu, S. W.; Wang, Z. Q.; Han, B. F.; Shu, G. M.; and Wang, T. 2008. Electron microprobe monazite geochronological constraints on the Late Palaeozoic tectonothermal evolution in the Chinese Tianshan. J. Geol. Soc. Lond. 165:511-522.

Li, X. P.; Zhang, L. F.; Ai, Y. L.; Qu, J. F.; Song, B.; and Liu, X. M. 2005. Zircons overprinted by rodingitization and their U-Pb ages from a serpentinite complex, western Tianshan. Mitt. Oesterr. Miner. Ges. 150:87.

Li, X. P.; Zhang, L.; Wei, C.; Ai, Y.; and Chen, J. 2007. Petrology of rodingite derived from eclogite in western Tianshan, China. J. Metamorph. Geol. 25:363-382.

Lin, W., and Enami, M. 2006. Prograde pressure-temperature path of jadeite-bearing eclogites and associated high-pressure/low-temperature rocks from western Tianshan, northwest China. Isl. Arc 15:477-496.

Lin, W.; Faure, M.; Shi, Y. H.; Wang, Q. C.; and Li, Z. 2009. Palaeozoic tectonics of the south-western Chinese Tianshan: new insights from a structural study of the high-pressure/low-temperature metamorphic belt. Int. J. Earth Sci. 98:1259-1274.

Liu, Y. M.; Yang, W. H.; and Gai, J. Y. 1994. Study on isotopic age of Dahalajunshan Formation in Tekesi forest of Xinjing. Geochimica 23:99-104 (in Chinese).

Lü, Z.; Zhang, L. F.; Du, J. X.; and Bucher, K. 2008. Coesite inclusions in garnet from eclogitic rocks in western Tianshan, northwest China: convincing proof of UHP metamorphism. Am. Mineral. 93:1845-1850.

Mikolaichuk, A. V.; Kotov, V. V.; and Kuzikov, S. I. 1995. Structural position of the Malyi Naryn metamorphic complex as related to the problem of the boundary between the north and median Tian Shan. Geotectonics 29:157-166 (English translation).

Mikolaichuk, A. V.; Kurenkov, S. A.; Degtyarev, K. E.; and Rubtsov, V. I. 1997. Northern Tien Shan: main stages of geodynamic evolution in the Late Precambrian-Early Paleozoic. Geotectonics 31:445-462 (English translation). 
Parra, T.; Vidal, O.; and Jolivet, L. 2001. Relation between deformation and retrogression in blueschist metapelites of Tinos Island (Greece) evidenced by chloritemica local equilibria. Lithos 63:41-66.

Platt, J. P. 1993. Exhumation of high-pressure rocks: a review of concept and processes. Terra Nova 5:119133.

Qian, Q.; Gao, J.; Klemd, R.; He, G. Q.; Song, B.; Liu, D. Y.; and Xu, R. H. 2009. Early Paleozoic tectonic evolution of the Chinese South Tianshan Orogen: constraints from SHRIMP zircon U-Pb geochronology and geochemistry of basaltic and dioritic rocks from Xiate, NW China. Int. J. Earth Sci. 98:551-569.

Renne, P. R.; Swisher, C. C.; Deino, A. L.; Karner, D. B.; Owens, T. L.; and DePaolo, D. J. 1998. Intercalibration of standards, absolute ages and uncertainties in ${ }^{40} \mathrm{Ar} /$ ${ }^{39}$ Ar dating. Chem. Geol. 145:117-152.

Rowley, D. B.; Xue, F.; Tucker, R. D.; Peng, Z. X.; Baker, J.; and Davis, A. 1997. Ages of ultrahigh pressure metamorphism and protolith orthogneisses from the eastern Dabie Shan: U/Pb zircon geochronology. Earth Planet. Sci. Lett. 151:191-203.

Ruffet, G.; Féraud, G.; and Amouric, M. 1991. Comparison of ${ }^{40} \mathrm{Ar} /{ }^{39} \mathrm{Ar}$ conventional and laser dating of biotites from the North Trégor Batholith. Geochim. Cosmochim. Acta 55:1675-1688.

Ruffet, G.; Féraud, G.; Ballèvre, M.; and Kiénast, J. R. 1995. Plateau ages and excess argon in phengites: an ${ }^{40} \mathrm{Ar}-{ }^{39} \mathrm{Ar}$ laser probe study of Alpine micas (Sesia Zone, western Alps, northern Italy). Chem. Geol. 121: 327-343.

Şengör, A. M. C., and Natal'in, B. A. 1996. Palaeotectonics of Asia: fragments of a synthesis. In Yin, A., and Harrison, T. M., eds. Tectonic evolution of Asia. Cambridge, Cambridge University Press, p. 486-640.

Şengör, A. M. C.; Natal'in, B. A.; and Burtman, V. S. 1993. Evolution of the Altaid tectonic collage and Paleozoic crust growth in Eurasia. Nature 364:299-307.

Shu, L. S.; Charvet, J.; Guo, L. Z.; Lu, H. F.; and LaurentCharvet, S. 1999. A large-scale Palaeozoic dextral ductile strike-slip zone: the Aqqikkudug-Weiya zone along the northern margin of the central Tianshan Belt, Xinjiang, NW China. Acta Geol. Sin. 73:148-162.

Shu, L. S.; Charvet, J.; Lu, H. F.; and Laurent-Charvet, S. 2002. Paleozoic accretion-collision events and kinematics of ductile deformation in the central-southern Tianshan Belt, China. Acta Geol. Sin. 76:308-323.

Shu, L. S.; Lu, H. F.; Charvet, J.; Laurent-Charvet, S.; and Yin, D. H. 2000. Paleozoic accretionary terranes in northern Tianshan, NW China. Chin. Geochem. 19: 193-202.

Shu, L. S.; Wang, B.; Yang, F.; Lu, H. F.; Charvet, J.; and Laurent-Charvet, S. 2003. Polyphase tectonic events and Mesozoic-Cenozoic basin-range coupling in the Chinese Tianshan Belt. Acta Geol. Sin. 77:457-467.

Simonov, V. A.; Sakiev, K. S.; Volkova, N. I.; Stupakov, S. I.; and Travin, A. V. 2008. Conditions of formation of the Atbashi Ridge eclogites (South Tien Shan). Russ. Geol. Geophys. 49:803-815.

Stupakov, S. I.; Volkova, N. I.; Travin, A. V.; Simonov, V.
A.; Sakiev, K. S.; and Novgorodtsev, O. S. 2004. Eclogites of Atbashi Ridge as indicators of Early Carboniferous collision in southern Tien Shan. Petrology of magmatic and metamorphic complexes 4. Tomsk, Tomsk Center for Scientific and Technical Information, p. 272-277.

Su, W.; Zhang, M.; Redfern, S. A. T.; Gao, J.; and Klemd, R. 2009. OH in zoned amphiboles of eclogite from the western Tianshan, NW-China. Int. J. Earth Sci. 98: 1299-1309.

Tagiri, M.; Yano, T.; Bakirov, A.; Nakajima, T.; and Uchiumi, S. 1995. Mineral parageneses and metamorphic P-T paths of ultrahigh-pressure eclogites from Kyrghyzstan Tien-Shan. Isl. Arc 4:280-292.

Van der Voo, R.; Levashova, N. M.; Skrinnik, L. I.; Kara, T. V.; and Bazhenov, M. L. 2006. Late orogenic, largescale rotations in the Tien Shan and adjacent mobile belts in Kyrgyzstan and Kazakhstan. Tectonophysics 426:335-360.

Wang, B.; Chen, Y.; Zhan, S.; Shu, L. S.; Faure, M.; Cluzel, D.; Charvet, J.; and Laurent-Charvet, S. 2007a. Primary Carboniferous and Permian paleomagnetic results from Yili Block and their geodynamic implications on evolution of Chinese Tianshan Belt. Earth Planet. Sci. Lett. 263:288-308.

Wang, B.; Cluzel, D.; Shu, L. S.; Faure, M.; Charvet, J.; Chen, Y.; Meffre, S.; and de Jong, K. 2009. Evolution of calc-alkaline to alkaline magmatism through Carboniferous convergence to Permian transcurrent tectonics, western Chinese Tianshan. Int. J. Earth Sci. 98: 1275-1298.

Wang, B.; Faure, M.; Cluzel, D.; Shu, L. S.; Charvet, J.; and Meffre, S. 2006. Late Paleozoic tectonic evolution of the northern West Tianshan, NW China. Geodin. Acta 19:237-247.

Wang, B.; Faure, M.; Shu, L. S.; Cluzel, D.; Charvet, J.; de Jong, K.; and Chen, Y. 2008a. Paleozoic tectonic evolution of the Yili Block, western Chinese Tianshan. Bull. Soc. Geol. Fr. 179:483-490.

Wang, B.; Shu, L. S.; Cluzel, D.; Faure, M.; and Charvet, J. 2007b. Geochemical constraints on Carboniferous volcanic rocks of the Yili Block (Xinjiang, NW China): implication for the tectonic evolution of Western Tianshan. J. Asian Earth Sci. 29:148-159.

Wang, B.; Shu, L. S.; Faure, M.; Cluzel D.; and Charvet, J. 2007c. Paleozoic tectonism and magmatism of Kekesu-Qiongkushitai section in southwestern Chinese Tianshan and their constraints on the age of the orogeny. Acta Petrol. Sin. 23:1354-1368 (in Chinese with English abstract).

Wang, B. Y.; Li, Q.; and Liu, J. B. 1997. Geological structures of the Middle Tianshan Mountains along the Dushanzi-Kuqa highway. Xinjiang Geol. 15:135-154 (in Chinese with English abstract).

Wang, X. C.; He, G. Q.; and Li, M. S. 1996. A discussion on the time of the Kuergan micro-massif in South Tianshan. J. Chengdu Univ. Technol. 23:90-95 (in Chinese with English abstract).

Wang, Y.; Li, J. Y.; and Sun, G. H. 2008b. Postcollisional eastward extrusion and tectonic exhumation along 
the eastern Tianshan Orogen, Central Asia: constraints from dextral strike-slip motion and ${ }^{40} \mathrm{Ar} /{ }^{39} \mathrm{Ar}$ geochronological evidence. J. Geol. 116:599-618.

Wei, C.; Powell, J. R.; and Zhang, L. F. 2003. Eclogites from the south Tianshan, NW China: petrological characteristic and calculated mineral equilibria in the $\mathrm{Na}_{2} \mathrm{O}-\mathrm{CaO}-\mathrm{FeO}-\mathrm{MgO}-\mathrm{Al}_{2} \mathrm{O}_{3}-\mathrm{SiO}_{2}-\mathrm{H}_{2} \mathrm{O}$ system. J. Metamorph. Geol. 21:169-179.

Windley, B. F.; Alexeiev, D.; Xiao, W. J.; Kroner, A.; and Badarch, G. 2007. Tectonic models for accretion of the Central Asian Orogenic Belt. J. Geol. Soc. Lond. 164: 31-47.

Windley, B. F.; Allen, M. B.; Zhang, C.; Zhao, Z. Y.; and Wang, G. R. 1990. Paleozoic accretion and Cenozoic redeformation of the Chinese Tien Shan range, Central Asia. Geology 18:128-131.

XBGMR (Xinjiang Bureau of Geology and Mineral Resources). 1979. Geological map, Zhaosu sheet (K-44$10)$, scale $1: 200,000$.

- 1981. Geological map, Quexiang sheet (K-44-16), scale $1: 200,000$.

1983. Geological map, Heiyingshan sheet (K-44$10)$, scale $1: 200,000$.

- 1993. Regional geology of Xinjiang Uygur Autonomous Region. Beijing, Geological Publishing House (in Chinese with English abstract).

Xiao, W. J.; Han, C. M.; Yuan, C.; Sun, M.; Lin, S. F.; Chen, H. L.; Li, Z. L.; Li, J. L.; and Sun, S. 2008. Middle Cambrian to Permian subduction-related accretionary orogenesis of northern Xinjiang, NW China: implications for the tectonic evolution of central Asia. J. Asian Earth Sci. 32:102-117.

Xiao, W. J.; Zhang, L. C.; Qin, K. Z.; Sun, S.; and Li, J. L. 2004. Paleozoic accretionary and collisional tectonics of the eastern Tianshan (China): implications for the continental growth of Central Asia. Am. J. Sci. 304: 370-395.

Xiao, X. C.; Tang, Y. Q.; Feng, Y. M.; Zhu, B. Q.; Li, J. Y.; and Zhao, M. 1992. Ophiolites in northern Xinjiang, China. In Tectonic evolution of the northern Xinjiang and its adjacent regions. Beijing, Geology Publishing House, p. 12-47 (in Chinese with English abstract).

Xiao, X. C.; Tang, Y. Q.; Li, J. Y.; Zhao, M.; Feng, Y. M.; and Zhu, B. Q. 1990. Geotectonic evolution of northern Xinjiang. Xinjiang Geol. Sci. 1:47-68 (in Chinese with English abstract).

Yang, T. N.; Li, J. Y.; Sun, G. H.; and Wang, Y. B. 2006. Earlier Devonian active continental arc in central Tianshan: evidence of geochemical analyses and zircon SHRIMP dating on mylonitized granitic rock. Acta Petrol. Sin. 22:41-48 (in Chinese with English abstract).
Yin, A., and Nie, S. Y. 1996. A Phanerozoic palinspastic reconstruction of China and its neighboring regions. In Yin, A., and Harrison, M., eds. The tectonic evolution of Asia. Rubey Colloquium. Cambridge, Cambridge University Press, p. 442-485.

Yin, A.; Nie, S. Y.; Craig, P.; Harrison, T. M.; Ryerson, F. J.; Qian, X. L.; and Yang, G. 1998. Late Cenozoic tectonic evolution of southern Chinese Tianshan. Tectonics $17: 1-27$.

Zhai, W.; Sun, X. M.; Gao, J.; He, X. P.; Liang, J. L.; Miao, L. C.; and Wu, Y. L. 2006. SHRIMP dating of zircons from volcanic host rocks of Dahalajunshan Formation in Axi gold deposit, Xinjiang, China, and its geological implications. Acta Petrol. Sin. 22:1399-1404 (in Chinese with English abstract).

Zhang, L. F.; Ai, Y. L.; Li, X. P.; Rubatto, D.; Song, B.; Williams, S.; Song, S. G.; Ellis, D. J.; and Liou, J. G. 2007. Triassic collision of western Tianshan orogenic belt, China: evidence from SHRIMP U-Pb dating of zircon from HP/UHP eclogitic rocks. Lithos 96:266280.

Zhang, L. F.; Ellis, D. J.; Williams, S.; and Jiang, W. 2003. Ultrahigh-pressure metamorphism in eclogites from the western Tianshan, China: reply. Am. Mineral. 88: 1157-1160.

Zhou, D.; Graham, S. A.; Chang, E. Z.; Wang, B. Y.; and Hacker, B. 2001. Paleozoic tectonic amalgamation of the Chinese Tianshan: evidence from a transect along the Dushanzi-Kuqa highway. In Hendrix, M. S., and Davis, G. A., eds. Paleozoic and Mesozoic tectonic evolution of central Asia: from continental assembly to intracontinental deformation. Geol. Soc. Am. Mem. 194:23-46.

Zhu, Y. F.; Zhang, L. F.; Gu, L. B.; Guo, X.; and Zhou, J. 2005. The zircon SHRIMP chronology and trace element geochemistry of the Carboniferous volcanic rocks in western Tianshan Mountains. Chin. Sci. Bull. 50:2201-2212.

Zhu, Y. F.; Zhou, J.; and Guo, X. 2006a. Petrology and Sr-Nd isotopic geochemistry of the Carboniferous volcanic rocks in the western Tianshan Mountains, NW China. Acta Petrol. Sin. 22:1341-1350 (in Chinese with English abstract).

Zhu, Y. F.; Zhou, J.; Song, B.; Zhang, L. F.; and Guo, X. $2006 b$. Age of the "Dahalajunshan" Formation in Xinjiang and its disintegration. Geol. China 33:487-497 (in Chinese with English abstract).

Zhu, Z. X. 2007. The geological components and tectonic evolution of south Tianshan, Xinjiang. PhD thesis, Chinese Academy of Geological Sciences, Beijing, 210 p. 